\title{
34-Hamdi Ülker’in eserlerinin kök değerler açısından incelenmesi
}

\section{Necdet TOZLU²}

\section{Buse Nur YÜCE3} APA: Tozlu, N.; Yüce, B. N (2020). Hamdi Ülker’in eserlerinin kök değerler açısından incelenmesi.
RumeliDE Dil ve Edebiyat Araştırmaları Dergisi, (21), 575-597. DOI: 10.29000/rumelide.843597.

\section{$\ddot{\mathbf{O} z}$}

Kültürel ve sosyal bir varlık olan insan, sahip olduğu değerleri, bireysel ve sosyal yaşamına anlam katmak, bu değerleri gelecek nesillere aktarmak ve bu değerlerle daha iyi bir gelecek inşa etmek gibi amaçlarla kullanmaktadır. Toplumsal bütünlüğü sağlamada çok büyük etkisi olan bu değerler, birçok kültürde olduğu gibi Türk kültüründe de edebi eserler ve öğretim ile genç nesillere aktarılmıştır. Yakın geçmişe kadar belirli bir plan dahilinde olmadan, genellikle derslerde doğrudan veya örtük program dahilinde değer iletimi sağlanmıştır. 2017 yılında ise Milli Eğitim Bakanlığı öğretim programı değişikliği içerisinde değerler eğitimi konusu ele alınmış ve değerler eğitiminin esası görülen on kök değere yer verilmiştir. Yapılan çalışmada Hamdi Ülker’in eserlerinin, milli eğitim bakanlı̆̆ının tespit ettiği öğretim programında yer alan on kök değer açısından incelenmesi amaçlanmıştır. Bu amaç doğrultusunda Hamdi Ülker'in 9 eseri kök değerler açısından incelenmiş, okuyucuya aktardığı değerler, değerler eğitimine sağladığı katkılar belirlenmiştir. Araştırma yöntemi için içerik analizi seçilmiş ve değerleri kayıt altına almak için fişleme tekniği kullanılmıştır. Araştırma sonucunda tespit edilen 437 adet değerde, en çok sevgi değerine en az ise adalet değerine rastlanılmıştır. Eserlerde tespit edilen on kök değer, şekiller aracılığıyla sılklık ve yüzdesel olarak belirtilmiştir. Eserlerin genelinde on kök değerin hepsine yer verildiği ve değerlerin okuyucuya örtük bir biçimde aktarıldı̆̆ı tespit edilmiştir.

Anahtar kelimeler: Değer, değerler eğitimi, Hamdi Ülker

\section{Analysis of Hamdi Ülker's works in terms of core values}

\begin{abstract}
Human beings use their values for purposes such as adding meaning to their individual and social life, transferring them to future generations, and building a better future with them. These values have been passed on to younger generations through literary works and education. Until recently, value transmission has been achieved in lessons without a specific plan. In 2017, the subject of values education was handled within the scope of the curriculum change of the Ministry of National Education and ten core values that form the basis of the values education were included in the new curriculum. The aim of the research is to examine the works of Hamdi Ülker in terms of ten core values in the curriculum. For this purpose, 9 works of Hamdi Ülker have been examined in terms of core values, and the values they have transferred to the reader sand their contribution to the
\end{abstract}

Bu makale, Erzincan Binali Yıldırım Üniversitesi Sosyal Bilimler Enstitüsünde sunulan aynı adlı yüksek lisans tezinden üretilmistir.

2 Doç. Dr., Erzincan Binali Ylldırım Üniversitesi, Eğitim Fakültesi, Temel Eğitim Bölümü (Erzincan, Türkiye), necdettozlu@hotmail.com, ORCID ID: 000o-0002-0466-1290. [Araştırma makalesi, Makale kayıt tarihi: 20.11.2020kabul tarihi: 20.12.2020; DOI: 10.29000/rumelide.843597]

3 YL Öğrencisi, Erzincan Binali Yıldırım Üniversitesi, Sosyal Bilimler Enstitüsü, Temel Eğitim ABD (Erzincan, Türkiye), busenryuce@gmail.com, 0000-0002-4042-2019

Adres İstanbul Medeniyet Üniversitesi, Eğitim Bilimleri Fakültesi, Türkçe ve Sosyal Bilimler Eğitimi Bölümü, Türkçe Eğitimi ABD Cevizli Kampüsü, Kartal-İstanbul/TÜRKIYY e-posta: editor@rumelide.com
Address

İstanbul Medeniyet University, Faculty of Education Sciences,

Turkish and Social Scinces Education, Turkish Language Teaching

Education, Cevizli Campus, Kartal-İstanbul /TURKEY

e-mail: editor@rumelide.com 


\begin{abstract}
education of the values have been determined. Content analysis was chosen for the research method and labeling technique was used to record the values. The determined values are shown with page number sand divided into classes and displayed in the header. At the end of the study, the most "love" value and the least "justice" value were determined at 437 values. The ten basic values determined in the Works are expressed as numbers in frequency and percentage. It was determined that all ten core values were included in the works and the values were implicitly transferred to the reader.
\end{abstract}

Keywords: Value, values education, Hamdi Ülker

\title{
1. Giriş
}

İnsan hem kültürel hem de sosyal bir varlık olarak sahip olduğu değerleri, bireysel ve sosyal yaşamına anlam katmak amacıyla kullanmakta; bunları gelecek nesillere aktarmakta ve yarattığı bu değerler aracılı̆̆ıyla daha iyi bir geleceği inşa etmeye çalışmaktadır. Dünya medeniyetine ışık tutan en önemli kültürlerden biri de Türk kültürüdür. Türk kültürü ya da Türk’ün yaşam biçimi, binlerce yıllık birikimiyle dünya medeniyetine evrensel ölçütlerde onlarca değer kazandırmıştır. Türk kültürüyle var olan değerler evrensel değerlerle örtüşen özelliklere sahiptir. Türk tarihinde, kültürel birikimin, kültür ürünü değerlerin nesiller boyu aktarımında, şair, yazar ve düşünürlerin yarattığı edebi eserlerin önemi büyüktür. Ayrıca hem milli hem de evrensel değerlerin nesiller boyu aktarımında okulların ve okullarda uygulanan öğretim programlarının da önemi çok büyüktür.

Türkiye'de değer iletimi belirli bir plan dâhilinde olmadan bazı derslerde doğrudan bazı derslerde ise örtük program içinde sağlanmıştır. Bu uygulama 2004 yllında pilot uygulamasına başlanan yapılandırmacı ilköğretim programlarıyla başka bir ivme kazanmış ve derslerde her ünitede doğrudan kazandırılacak değerler gösterilmeye başlanmıştır. 2005 yllında uygulamaya geçen Sosyal Bilgiler öğretim programında değerler eğitimine çok önem verildiği görülmektedir. Sosyal bilgiler dersi 4-5 ve 6-7. sınıf öğretim programında, öğrencilere kazandırılacak değerler ve bu değerlerin eğitimi, ayrı bir başlık altında oluşturulmuş ve öğrenciye verilmesi gereken değerler saptanmıştır. (Yel \& Aladağ, 2009).

Ülkemizde değerler eğitimi 2010 $\square 2011$ Öğretim Yllı’ndan itibaren başlamıştır. Bu yıldan sonra okullar değerler eğitimi çalışmalarına yer vermiştir. 2017 yılında Milli Eğitim Bakanlığı öğretim programa on kök değer eklenmiştir. Değerler ve değer eğitimi, öğretim programlarının nirengi noktasını oluşturmuştur. Ayrıca değer eğitiminin önemi vurgulanarak mevcut öğretim programları içinde ele alınması gereği vurgulanmıştır.

\subsection{Problem durumu}

Nitelikli bir eğitim sisteminden beklenen en önemli sonuçlardan biri, yetiştirilen bireylerin davranışlarını sürekli olumlu değişiklikler yaratabilecek yeterliklerle geliştirmektir. Örgün eğitim yaşantıları aracılığıyla bireylere, ülke kültürünün sahip olduğu değerler kazandırılmaya çalışılır. Değerler, edebi metinlerde, halkın davranış örüntülerinde, kültürün aktarım şekillerinde görülür. Önemli olan değerlerin gerçekliklerine uygun bir şekilde öğrencilerin davranışlarında sergilenmesi gerekliliğidir. Davranışlara aktarılmayan değerler, hem kuramsal hem de uygulama pratiklerine bağlı olarak önemli bir anlam ifade etmez. Değerlerin davranışlarda gösterilememesi probleminin etkili bir şekilde çözümü için okullardaki sosyal etkinliklere gereken özenin gösterilmesi gerekir.

\footnotetext{
Adres $\mid$ Address

İstanbul Medeniyet Üniversitesi, Eğitim Bilimleri Fakültesi, Türkçe ve Sosyal Bilimler Eğitimi Bölümü, Türkce Eğitimi ABD Cevizli Turkish and Social Scinces Education, Turkish Language Teaching Kampüsü, Kartal-İstanbul/TÜRKIYE Education, Cevizli Campus, Kartal-İstanbul /TURKEY e-posta: editor@rumelide.com $\mid$ e-mail: editor@rumelide.com
} 
Toplumlar değerlerini sürdürebilmek için gelecek kuşaklarını bu değerlerle mücehhez yetiştirmeye çalışırlar. Sorumluluk sahibi, ait olduğu topluma uyumlu, değerlerini önceleyen ve yaşatan bireyler yetiştirmenin yanında değer kaybını önlemek amacıyla çaba sarf ederler. Dünyada yaşanan hızlı gelişmeler, toplumun temelini oluşturan değerleri de büyük ölçüde etkilemiştir. İçinde bulunduğumuz dijital çă̆, baskın kültürlerin diğer kültürleri etkilemesine hatta temel değerlerinde değişikliğe sebebiyet vermektedir. Yaşanan bu değişiklikler, aile birliğinin dağılması, güvenli ve huzurlu ortamın sağlanamaması gibi toplumsal sorunlara yol açmaktadır. Bu tür sorunların gün geçtikçe artarak devam ediyor olması etkili bir değer eğitimi ihtiyacının göstergesidir. Asıl mesele, aktarılması hedeflenen değerlerin, gelecek kuşaklara ne tür araçlarla kazandırılabilir olmasıdır (Ekşi, 2003). Yazarlar, roman ve hikâyelerinde düşünce ve duyguların yanında ait oldukları toplumların değerlerini de okuyucuya aktarırlar. Bu nedenle Hamdi Ülker’in eserleri öğretim programında belirtilen on kök değer açısından incelenmiştir.

\subsection{Alt problemler}

a. Hamdi Ülker eserlerinde hangi kök değerleri ön plana çıkarmıştır?

b. Hamdi Ülker’in eserlerinde tespit edilen değerlerin dağılımı ne sıklıktadır?

c. Hamdi Ülker’in eserleri değerler eğitiminde kullanılması mümkün kaynaklar mıdır?

\section{Yöntem}

\subsection{Araştırma yöntemi}

Bilimsel araştırmalarda yöntemler nicel ve nitel olmak üzere iki başlı̆̆a ayrılmıştır. Nitel araştırmalar, gözlem, görüşme ve doküman analizi gibi nitel veri toplama yöntemlerinin kullanıldığı, algıların ve olayların doğal ortamda gerçekçi ve bütüncül bir biçimde ortaya konmasına yönelik nitel bir sürecin izlendiği araştırmalardır (Yıldırım \& Şimşek, 2018). Dokuman analizinde ulaşılan veriler bir bilgi tabanında yer alabilir. Araştırmacılar analizi yapılacak dokümanlar için kütüphane kataloglarına ve arşivlerine göz atarak, bilinmeyeni belgeleyebilir. Doküman analizi, diğer araştırma metotlarına göre daha az zaman alması, daha az maliyetli olması ve detaylı incelemelere firsat vermesi yönüyle kullanışlıdır (Bowen, 2009). "Nitel araştırmanın temelinde kuram oluşturma ve sosyal olguları kendi imkânları içerisinde değerlendirip anlaşılır kılma esası vardır” (Yıldırım \& Şimşek, 2018). Araştırmacılar kendiliğinden, doğal olarak oluşan olguları tüm karmaşıklığı içerisinde irdeler (Fraenkel \& Norman, 2000). Nitel araştırma olan bu çalışma, değerler eğitimi yönüyle Hamdi Ülker'in eserlerini incelemeyi amaçlamıştır. Eserlerdeki değerler, içerik analizi yöntemi ile değerlendirilecektir.

\section{2. İncelenen dokümanlar}

Araştırmada incelenen dokümanlar Hamdi Ülker'e ait, yayımlanmış 9 kitaptır. Bu eserler Tablo 1'de belirtilmiştir.

Adres

İstanbul Medeniyet Üniversitesi, Eğitim Bilimleri Fakültesi, Türkce ve Sosyal Bilimler Eğitimi Bölümü, Türkçe Eğitimi ABD Cevizli Kampüsü, Kartal-İstanbul/TÜRKIYE e-posta: editor@rumelide.com
Address

İstanbul Medeniyet University, Faculty of Education Sciences,

Turkish and Social Scinces Education, Turkish Language Teaching

Education, Cevizli Campus, Kartal-İstanbul /TURKEY

e-mail: editor@rumelide.com 
Tablo 1. Hamdi Ülker’in Eserlerinin Künyesi

\begin{tabular}{l|l|l|l}
\hline Eserin Adı & Tür & Basım Yeri & Basım Yılı \\
\hline 1914-90ooo Sarıamış & Roman & Konya & 2011 \\
\hline Dergah & Roman & Konya & 2012 \\
\hline Son cemrem & Öykü & İstanbul & 2014 \\
\hline Bana aşkı anlatır mısın? & Roman & İstanbul & 2014 \\
\hline Doğu ekspresi & Öykü & İstanbul & 2015 \\
\hline Kardelene Mektuplar & Öykü & İstanbul & 2015 \\
\hline Gökmavi & Roman & İstanbul & 2015 \\
\hline Yedi levin akşamı & Öykü & İstanbul & 2017 \\
\hline
\end{tabular}

Çalışmada alan yazında daha önce hiç çalışılmamış olan Hamdi Ülker'in eserlerinin okullarda değer eğitimine katkı sağlayacak ek kaynaklar arasında olabileceği düşünüldüğü için dokuz eserinin milli eğitim bakanlığı tarafından tespit edilen öğretim programında belirtilen on kök değer açısından incelenmesi uygun görülmüştür.

\subsection{Verilerin toplanması}

Hamdi Ülker’in 9 eseri ele alınarak çalışmanın amacı bağlamında irdelenmiş ve gerekli veriler tespit edilmiştir. Kuramsal çerçeve için Milli Eğitim Bakanlığının müfredatında yer alan değerlere ilişkin kaynak kitaplar incelenmiş, bilimsel değeri ve kabulü olan kitaplardan bilimsel çerçeve oluşturulmuştur. Yazar hakkındaki bilgiler ailesi, arkadaşları ve diğer yakın çevresiyle yapılan sohbetlerle ortaya çıkarılmıştır. Veriler, "Sohbet tarzı görüşme" ve "Nitel doküman incelemesi" yoluyla elde edilmiştir.

\subsection{Verilerin analizi}

TTKB’nin 18 Temmuz 2017 tarihinde "Müfredatta Yenileme ve Değişiklik Çalışmalarımız Üzerine" başlı̆̆ıyla yayınladığı bu bildirisinde "Değerler Eğitimi”ne ilişkin "on kök değer"den bahsedilmiştir. Bahsi geçen değerler "adalet, dostluk, dürüstlük, öz denetim, sabır, saygı, sevgi, sorumluluk, vatanseverlik, yardımseverlik” olarak sunulmuştur. Yazara ait eserlere ulaşılmış ve tamamı okunup MEB'in değerler eğitimine ilişkin bahsettiği on kök değer tespit edilip bulunduğu sayfalarla birlikte gösterilmiştir. Tespit edilen değerler, içerisinde yer aldığı kitapların baş harfleri ile kodlanmıştır. Tespit edilen değerler cümle sonundaki parantez içerisinde kitabın kodu, basım tarihi ve bulunduğu sayfa sayısı ile belirtilmiştir. Analiz için betimsel analiz yöntemi kullanılmıştır. Yapılan çalışma sonucunda Hamdi Ülker'in eserlerinde yer alan değerler tespit edilmiş ve hangi değerlere daha fazla vurgu yapıldı ğı analiz edilmiştir.

Adres 


\section{Bulgular ve yorum}

\subsection{Tespit edilen kök değerlerin analizi}

\subsubsection{Adalet}

Adalet, karşılıklı insan ilişkilerini düzenleyen toplumsal düzenin mümkün, ama zorunlu olmayan bir niteliğidir (Kelsen, 2013). Hökelekli (2008) adalet kavramını "yerli yerine koymak, her hakkı hak sahibine vermektir. Hüküm ve davranışlarında tarafsız ve ilkeli olmak, eşitliği gözetmektir. Menfaat, yakınlık, düşmanlık, önyargı ve benzeri nedenlerin etkisinden uzak, doğru ve dürüstçe iş yapmaktı»" şeklinde tanımlamaktadır. Adalet, doğruluk, dürüstlük, eşitlik, hak, hak yemezlik, hakkaniyet ölçülerine uyma, meşruluk, tarafsızlık, insaniyet, iyilik gibi anlamlara gelir (Tan \& Töremen, 2010).

$\mathrm{Bu}$ tanımlardan yola çıkarak bir toplumda düzenin sağlanması, o toplumdaki bireylere eşit yaklaşılması ve ayrım gözetmeksizin her biri için aynı kurallar aynı haklar geçerli olmalıdır diyebiliriz. Toplumdaki fertler herkes için aynı adaletin geçerli olmadığını düşünürse toplumda huzursuzluklar baş gösterir. Barış, huzur ve güven dinamiklerinin temelini oluşturan adalet ancak uygulandığı takdirde toplumda düzen sağlanır. Adaletin uygulanmasının önemi gereği şimdiki ve gelecekteki nesillere bu değerin aktarılması gelecekteki toplum huzuru ve devamı açısından önemlidir.

Melek, durumu iyi olmayan bir ailede annenin var olan bir ekmeği herkese eşit şekilde pay edişini görmüştür. "Gün içerisinde ailenin küçük çocuklarmdan birisinin ele geçirdiği bir ekmeği, anne ile fertlerinin sayısı kadar payetmiş ve herkes hakkına düşene razı olmuştu. Haklarına o günlük düşen bir parça ekmeğe razı olup, yarısı açık barakada eski bir battaniyenin altına girip yatıp uyumuşlardı"(BAA, 2014).

Tablo 2. Eserlerde “Adalet” Değerinin Dağılımı

\begin{tabular}{l|l}
\hline Eserin Adı & Sayfa Numarası \\
\hline Bana Aşkı Anlatır (BAA) Mısın? & $189-226$ \\
\hline Dergâh & $3-17-38-166-209$ \\
\hline Son Cemrem & 114 \\
\hline
\end{tabular}

Dergâh'ta; ylllarca dağlarda kaçak gezen Mahmut, sonunda yakalanıp hapishaneye girmiştir. Elbistan Hapishanesi'nden firar ettiği gibi Sinop’tan da firar edeceğini düşünmüş ancak eşkıya yaftası yemiş ve hücreye kapatılınca umudu kalmamıştır. Bugüne kadarki yanlışlarının cezasını çektiğini düşünmüştür.

Dergâh'ta; ölümü bekleyen Mahmut affedilince, bir daha eskiye dönmemeye karar vermiştir. Samsun'da parasız ne yapacağı ve memleketine nasıl döneceğini düşünürken bir balıkçıyla tesadüfen tanışmış ve yanında işe başlamıştır. Bekçilik yaptığı iş yerinde bakıma muhtaç bir köpeğe bakmaktadır. Memleketine gitmek için aylardır beklediği gemi geldiği halde, Çomar ağır basmış ve gitmekten vazgeçmiştir.

Son Cemrem'de; müflis tacir Pire Mehmet'in Erzincan, Erzurum ve Bayburt civarında, köylerdeki insanları dolandırdığına dair şikâyetler gelmesi üzerine savcılık tarafından yakalama kararı çlkartılmıştır.

Adres

İstanbul Medeniyet Üniversitesi, Eğitim Bilimleri Fakültesi, Türkce ve Sosyal Bilimler Eğitimi Bölümü, Türkçe Eğitimi ABD Cevizli Kampüsü, Kartal-İstanbul/TÜRKIYE e-posta: editor@rumelide.com
Address

İstanbul Medeniyet University, Faculty of Education Sciences,

Turkish and Social Scinces Education, Turkish Language Teaching

Education, Cevizli Campus, Kartal-İstanbul /TURKEY

e-mail: editor@rumelide.com 


\subsubsection{Dostluk}

Türkçe sözlüklerde 'dost, sevilen, güvenilen, yakın arkadaş; gönüldaş, iyi görüşülen kimse, birbirini seven kişilerden her biri' olarak ele alınmıştır (Albayrak, 2004). Dost farsça bir kelimedir, 'sevgili' anlamına gelir. Birbirlerini karşlıksız ve riyasız seven anlamına gelir. Dost, arkadaşlığın çeşitli süreçlerden geçerek ulaştığı, adeta olgunlaştığı sürecin son noktasıdır (Poyraz, 2012).

Bireyler, zamanını paylaştığı gibi sırlarını, güzel anlarını, hayatını paylaşmak için doğru insanları seçtiğinde huzurlu bir hayat sürerler. Kendisi mutlu olan birey içinde bulunduğu çevreyi de mutlu eder yani toplumların huzuru bireylerin huzurundan geçmektedir. Toplumda birbirlerinin mutluluğu için çabalayan ve birbirleri için çaba gösterecek kişilere ihtiyacı vardır. Bu bilincin oluşturulması için gelecek kuşaklara aktarılması hedeflenen değerler arasında dostluk değeri büyük önem arz etmektedir. Mert yeni tanıştı̆̆ Melek ile hafta sonu birlikte vakit geçirmeyi planlar. Ancak Melek istemese bile arkadaşı için planını değiştirmeyeceğini söyleyerek arkadaşına sadık kalır. "Evet, gitmem lazım, aslına bakarsanı ben de istemezdim gitmeyi ama bir arkadaşımın mutlu günü. Bu mutlu gününde yanında olmam lazım"(BAA, 2014).

Ailesinde yaşanan problemler nedeniyle çocuk yuvasına verilen Melek, yeni evi olan yuvada tanıştığı Gökşen ile dostluklarını kardeşlermiş gibi bir tutku ile yıllarca yaşatmışlardır. “Gökşen’le çocuk yuvasında başlayan kardeşliğimiz Eğitim Fakültesine kadar birlikte sürmüsstü. O nasıl tutkuymuş öyle"(BAA, 2014).

Kendi sıkıntıları için boğuşurken Mustafa'nın öksürük nöbetleri Mert'i, Mustafa'ya yardımcı olmaya yöneltmiştir. "Mustafa'nın arada bir tutan öksürük nöbetleri kafama iyice takılmıştı. Her defasında sorduğumda üşüttük toprağım herhalde deyip geçiştiriyordu. Yine de reddetmesine rağmen onun bu içimi tırmalayan öksürüğünü doktora göstermeden bu şehirden ayrılmayı düşünmüyordum"(BAA, 2014).

Tablo 3. Eserlerde “Dostluk” Değerinin Dağılımı

\begin{tabular}{l|l}
\hline Eserin Adı & Sayfa Numarası \\
\hline Bana Aşkı Anlatır Mısın? & $\begin{array}{l}42-48-69-70-74-87-88-90-94-103-104-107-123-124-(126,127)-130-141- \\
166\end{array}$ \\
\hline Dergâh & $7-15-37-39-40-46-48-48-53-132$ \\
\hline Gökmavi & $17-153$ \\
\hline Kanayan Çiçekler Zamanı & $39-53$ \\
\hline Kardelene Mektuplar & 80 \\
\hline Sarıkamış & $66-70-128-180$ \\
\hline Yedi Levin Akşamı & 6 \\
\hline
\end{tabular}

Mert'in gitme kararını anlayışla karşılayarak nasıl isterse öyle yapmasını söylemiştir. "Başımı sallayarak, "biliyorum da derdine merhem olabilir miyim belki diye gitmeni istemiyorum, yoksa

Adres

İstanbul Medeniyet Üniversitesi, Eğitim Bilimleri Fakültesi, Türkçe ve Sosyal Bilimler Eğitimi Bölümü, Türkçe Eğitimi ABD Cevizli Kampüsü, Kartal-İstanbul/TÜRKIYE e-posta: editor@rumelide.com
Address

İstanbul Medeniyet University, Faculty of Education Sciences,

Turkish and Social Scinces Education, Turkish Language Teaching

Education, Cevizli Campus, Kartal-İstanbul /TURKEY

e-mail: editor@rumelide.com 
bilsem ki, seni bekliyor durma git diyeceğim kalmak istesen bile kovardım seni” diyerek gülümsedi üzgünlüğümü dağıtmak için... Hal adamıydr Mustafa’m, halden bilirdi...”(BAA, 2014).

Mert ayrılık kararı aldığı Melek ile gittiği mekanlardan tanıştığı Çingene dostu ile baş başa dertleşmektedir. O sırada başka bir dostu olan Aşık Yener masalarına gelir, ama bir konu üzerine konuştuklarının bilinciyle onları baş başa bırakarak anlayış gösterir. "Sevgili dostum, nerelerdesin uzun zamandır, görüşemez olduk." Diyerek masamıza teşrif ediyordu. Ayă̆ı kalktım nedendir bilmem ama büyük bir özlemle kendisine sarlldım. Oturması için ettiğim bütün ısrarlarl, bizi baş başa bırakmak için kabul etmediğini anlamıştım"(BAA, 2014).

Mert sevda acısı, dostu Mustafa'nın hastalığı derken iyice bunalmıştır. Bu yaşadıklarını anlatıp biraz olsun rahatlayacağı bir dostun eksikliğini hisseden Mert dostlukla ilgili düşüncelerini ifade etmiştir. "Hep bir dostu olmah insanın diye düşünüyorum. Hem de sarp bir uçurumun kenarmda korkusuzca yaslanabileceği bir dost. İyi günlerinden çok sıkıntıl günlerinde yüreği ile birlikte insanın yanında olacak bir dost. Sir saklayabilen, paylaşmayı da bir o kadar becerebilen yürekli, duygulu bir dost"(BAA, 2014).

Mert, işlerinin yoğunluğuyla arayamadığı Mustafa'nın öldüğünü öğrenince, acısını hafifletmek için onu yazmaya başlar. Dostu artık olmasa da yüreğinde ona ayırdığı yerin hep duracak olması Mert’in ona olan vefasını göstermiştir. "Yüreğim yanıyor, içerim sızhyordu. Bir yandan yüreğimi gözyaşlarımla soğutmaya çalışıyor, bir yandan da içimdeki acıyı bir nebze azaltır umuduyla elimdeki kâğıtla dertleşiyor Mustafa'yı anlatmaya çalışıyordum. O yoktu artık, gitmişti ama yüreğimdeki Mustafa'mın sevgisi, ona ayırdığım yer onunla dopdolu duruyordu" (BAA, 2014).

Melek yeni görev yeri olan Trabzon'daki okuldan meslektaşının teklifi ile geçmişte yaşadığ çocuk yuvasını ziyareti onu duygulandırmış ve bu gördüğü yakınlıktan dolayı bir dost daha kazanmıştır. "Bana yaşattığı bu duygu yüklü anlardan sonra Sevim Öğretmen'e olan güvenim ve yakınhğım iyice artmıştı. Yine bir anda bir dost daha kazanmıştım”(BAA, 2014).

Melek ailesinden ayrılınca konuşmama kararı almıştır. Bir soruya arkadaşının esprili cevap vermesi üzerine sinıftaki herkesle birlikte Melek'te gülmüss ve hayata yeniden merhaba demiştir. Artık dostu Gökşen ile bir şeyler paylaşmaya başlamıştır. "Doktorun bile çözemediği dilim yapılan bir latifenin ardından kendiliğinden çözülmüş ve en yakın arkadaşlarımdan birisi olan Gökşen ile artık bazı şeylerimi paylaşmaya başlamıştım”(BAA, 2014).

Mahmut'un aklına, Sinop Hapishanesi'ndeki hücredeyken Elbistan Hapishanesi'ndeki koğuş arkadaşlarıyla kaçış planı yaptıkları o geceki anıları gelmiştir. "O gece kader arkadaşlarımla birlikte muhabbet ediyor, Erzurumlu İbrahim’in yank sesinden "dün gece yar hanesinde yastığım bir taş idi" türküsünü dinliyorduk"( $D$, 2012).

Cezaevinden çıktıktan sonra bir balıkçı barınağında Osman Reis sayesinde işe giren Mahmut şu fani dünyadaki tek dostu olan Osman Reis'in, bir süredir para meselesi yüzünden sorun yaşadığı kayınbiraderi tarafından sırtından bıçaklanarak öldürüldüğünü öğrenmiştir. "O yoktu artık. Şu fani dünyada tek dostum, tek ahbabımd. Çomar da yaral ve can çekişiyor. $O$ da giderse birkaç ay öncesinde olduğu gibi yine şu yaban ellerde bir başıma kalacağım”(D, 2012).

Mahmut'un, Osman Reis'ten sonra kendisine yol arkadaşı olan Çomar günlerdir verdiği hayat mücadelesini kaybetmiştir. Çomar’a bakmak için yıllardır hayalini kurduğu memleketine dönme

\footnotetext{
Adres $\mid$ Address

İstanbul Medeniyet Üniversitesi, Eğitim Bilimleri Fakültesi, Türkçe İstanbul Medeniyet University, Faculty of Education Sciences, ve Sosyal Bilimler Eğitimi Bölümü, Türkçe Eğitimi ABD Cevizli $\quad$ Turkish and Social Scinces Education, Turkish Language Teaching Kampüsü, Kartal-İstanbul/TÜRKIYE Education, Cevizli Campus, Kartal-İstanbul /TURKEY e-posta: editor@rumelide.com $\mid$ e-mail: editor@rumelide.com
} 
firsatını bile geri çeviren Mahmut bundan hiç pişman olmamış, Çomar'ın bir dostluk örneği olduğunu düşünmüştür. "Bu sabah erkenden kalkıp en sevdiğim dostlartmdan birisi ile de vedalaşarak onu Karadenizin soğuk sularına teslim etmiştim. O saatten bu yana ise gözümün yaşı kurumamışt. Can dostlarmdı onlar benim" $(D, 2012)$.

Ermeniler ile yaşanan gerginlik nedeniyle çoğu Ermeni gitmesine rağmen Erzurumlular Agop'u korumuş çünkü o güne kadar hiçbir yanlışını görmemiştir. Agop’ta vatanı bellediği Erzurum’u bırakıp gitmemiştir. "Birinci Cihan Harbi yıllarında Ermeniler ile yaşanan gerginlikler ve Ermenilerin Anadolu insanımın sinesinde açtıkları yaralar henüz iyileşmemişti ki benim bir Ermeni ile dostluğum devam ediyordu. Onlar da çok yıpranmışlardı"(D, 2012).

Oğlu Agit’in kendisinden bir şeyler gizlediğini fark eden Agop Mahmut için yakınlarına yazdığı mektubu görmüştür. Bugüne kadar davranışlarına çok dikkat eden Agop bunun öğrenilmesi ile işinden, yurdundan olabileceğinin farkındadır ancak oğlunun niyetinin yalnızca Mahmut’a iyilik etmek olduğunun bilincindedir. "Yaşlı adam oğlunun aslında can dostuna yardım etmekten başka bir niyetin olmadığımı anlamıştı. Ama bu onlar için çok büyük bir sıkıntı olabilirdi”( $D$, 2012).

Dağlarda arkadaşları ile gezen Mahmut konaklamak için bir köye inerler. İzi olmayan bir köyde namı pek bilinmediği için köylüler başlangıçta korkmuş olsa da güven verme çabaları sonucu Mahmut ile dost olmuşlardır. "Ben ve arkadaşlarım onların korkularını yersiz olduğunu söz ve davranışlarımız ile göstermeye çalışıyor, köylülere güven vermeye çalışıyorduk. Bu çabamız sonuç vermiş çok kısa sürede kaynaşmış ve dost olmayı başarmıştık”(D, 2012)

Asaf her akşam eski okul sıralarında yaptığı gibi kafasını masanın üzerine koyup, boynu ağrıyıncaya kadar uyumuş uyandıktan sonra sevgili dostu Gökmavi'ye bir şeyler karalamıştır. "Her akşam bir süre böylece uyuyup ardindan da uyandıktan sonra sevgili dostum Gökmavi’nin tütün kolonyası kokulu narin yapraklarına günün özetini karalayıp sonra da okuduğum kitaplara dalı gidiyordum"(G, 2015).

Ylllar sonra ilk görev yeri Adıyaman'ı ziyaret eden Asaf'ın ilk gittiği yer oradaki esnaf dostu Habip olmuştur. "Bu şehre geldiğim ilk iki yılımı yazdığım ve askerlikten sonra yaptığım bir otobüs yolculuğunda kaybettiğim günlüğüme tekrar kavuşmuştum. Şimdi ise ilk işim o yıllardan sonra esnaf, müşteri ilişkisinden çok candan dost olduğum Habip’i ziyaret etmek olacaktı"(G, 2015).

Berberi ile dost olduğu için her ayın belirli günü gelir hem saçını toplattırır hem muhabbetini ederdi. Bir süredir denk gelememiş olsalar da günümüz şaşsa da gönlümüz, muhabbetimiz şaşmadı diye düşünmüştür. "Kaç zamandır ben ayn günlerde gelemiyordum. Geldiğim zamanlarda ise çırak gidip onu sağdan soldan toplayıp dükkâna getiriyordu. Olsun! Günümüz şaşmıştı belki ama gönlümüz, muhabbetimiz şaşmamıştı"(KÇZ, 2017).

Kahraman yüreğindeki sevdası Kardelen'den uzun zamandır ayrı kalmıştır. Yüreğinin yine buza kestiği bir akşam dostu Hikmet Bey'in yanına gitmiştir. "Şehrin aksakallhlarından bir dostun yüreğine slğındım bu akşam ve onun, adı gibi hikmetli sözleri alp götürdü beni ta uzaklara. Hikmet Köksal Ağabey anlatıyor, yüreğimdeki dervişle ben can kulağıyla dinliyorduk"(KM, 2015).

Horasan'daki karargâha yetiştirilen Halil, sıhhiye çadırında pansuman edilirken Kasım'la birbirlerini tanımışlardır. "Yanı başına çömeldi ve birbirlerine gözleri dolu dolu olarak bakmaya başladılar.

\footnotetext{
\begin{tabular}{r|l} 
Adres & $\begin{array}{l}\text { Address } \\
\text { İstanbul Medeniyet Üniversitesi, Eğitim Bilimleri Fakültesi, Türkçe }\end{array}$ \\
İstanbul Medeniyet University, Faculty of Education Sciences,
\end{tabular} ve Sosyal Bilimler Eğitimi Bölümü, Türkçe Eğitimi ABD Cevizli Turkish and Social Scinces Education, Turkish Language Teaching Kampüsü, Kartal-İstanbul/TÜRKIYE $\quad$ Education, Cevizli Campus, Kartal-İstanbul /TURKEY e-posta: editor@rumelide.com 1 e-mail: editor@rumelide.com
} 
Kasım ile birlikte Köprüköy'de başlayan ve Sarıkamış yakınlarındaki karargâha kadar devam eden acı dolu bir yolu arkadaşlıkları vardı"(S, 2011).

Halil evlenmiş ve bir oğlu olmuştur. Etnik sürtüşmelerin çok olduğu günlerde doğmuştur oğlu. Eşi doğum yaparken dışarıda ondan gelecek haber bekleyen Halil, Ali Rıza Dede ile muhabbet etmiştir. Muhabbetlerini tazelemek için Ali Rıza Dede ile bir araya gelen Halil doğan oğluna Ali Rıza ismini vermiştir. "Ali Rıza Dede bu asil davranış karşısında söyleyecek hiçbir şey bulamamış ve çok duygulanmıştı. Belki asırlar sürecek bir dostluğun, ahbaplığın temelini atmıştı bu hoş davranışı ile Halil"(S, 2011).

Öyküdeki karakter her zaman olduğu gibi sabahın ilk saatlerinde evden çıkmış elindeki asaya yüklenerek dostları Çınar ile Kaya'nın yanına gitmiştir. "Çınar ile Kaya! Bu kış yine çok uzun ve soğuktu, değil mi? Sizler benim bu dünyadaki en iyi dostlarımsınız. Uzun zamandan beri yanınıza gelsem de çok kalamıyor sizinle muhabbeti çok sevmeme rağmen çabuk gidiyordum”(YLA, 2017).

\subsubsection{Dürüstlükk}

“TDK sözlükte dürüstlüğün tanımı "doğruluk” olarak geçmektedir (2005).” Kurulan her ilişkide temel gereksinim olan dürüstlük bireyin yaşadığı toplumda kabul edilebilirliği için de şarttır. Bireylerin daha küçük bir çocukken dürüstlük değeriyle ailede, toplumda karşılaşması ileride hizmet edeceği, sorumlulukları olacağı topluma kazandırılması açısından çok önemlidir. Toplumların birlikteliği için sözünde duran, etik davranan doğru sözlü bireylere ihtiyacı yadsınamaz bir gerçektir.

Tablo 4. Eserlerde “Dürüstlük” Değerinin Dağılımı

\begin{tabular}{l|l}
\hline Eserin Adı & Sayfa Numarası \\
\hline Bana Aşkı Anlatır Mısın? & 29-58-60-103-115-127-128-153-159 \\
\hline Doğu Ekspresi & 17 \\
\hline Son Cemrem & 115 \\
\hline Yedi Levin Akşamı & 13 \\
\hline
\end{tabular}

Mert evinden geçirdiği üç ayrı ay boyunca yaşadıklarını tüm yalınlığıyla eşine anlatma kararı vermiştir. İkiyüzlü bir insan olmaktansa tepki göreceğini bildiği halde eşine karşı dürüst olmayı seçmiştir. "Hayır, bu böyle daha fazla süremezdi ve sürmemeliydi. Kopacaksa da bir yerden kopmalıyd, daha fazla ikiyüzlü yaşayamazdım. Bu akşam eşime yaşadıklarımı anlatıp, bu halden kurtulmahydım. Her geçen gün biraz daha ağırlaşan bu yükü üzerimden az da olsa atmahydım. Artık kaldırmaya ve taşımaya mecalim kalmamış, altında son çırpınışlarımı yaşıyor gibiydim”(BAA, 2014, s.115)."Dürüstlük etmiş, kul hakkından korktuğum, aldatmayı kabullenemediğim için yaşadıklarmı bana en yakın olması gereken insanla paylaşmıştım ama nafile, o yükte omuzlarıma başka bir türlü binmişti..."(BAA, 2014).

Mercan Gar'ında kara treni bekleyen yolcular acıkmıştır. İçeriye simit satan bir adam girmiş, herkes birer ikişer simit almıştır. Yaşlı bir adam ucuza alabilmek umuduyla fiyatını sormuş yirmi lira olduğunu öğrenince simitçiye tepki göstermiştir. “Ali”nin adın taşıyan birisinin insanları kazıklaması

Adres

İstanbul Medeniyet Üniversitesi, Eğitim Bilimleri Fakültesi, Türkçe ve Sosyal Bilimler Eğitimi Bölümü, Türkçe Eğitimi ABD Cevizli Kampüsü, Kartal-İstanbul/TÜRKIYE e-posta: editor@rumelide.com
Address

Istanbul Medeniyet University, Faculty of Education Sciences,

Turkish and Social Scinces Education, Turkish Language Teaching

Education, Cevizli Campus, Kartal-İstanbul /TURKEY

e-mail: editor@rumelide.com 
doğru mu? Diyor ve simit almadan geriye dönüyor, ağzından bir şeyler geveleyerek az önce kalktı̆̆ sandalyeye geri oturuyordu"(DE, 2015).

\subsection{4. Öz denetim}

TDK sözlükte öz denetim kavramının tanımı "daha önemli bir amaca ulaşabilmek için kişinin tepkilerini, davranışlarını veya başka amaca yönelme eğilimini denetleyip kısıtlaması, otokontrol" olarak geçmektedir (2020). Kişi toplumda bir amaca ulaşmak için kendi davranışını kontrol edebilmeli, davranışlarının sorumluluğunu alabilmelidir. İnsanlar her zaman dışsal uyaranları dikkate almazlar yani herkes kanunlara göre hareket etseydi kimse suç işlememiş olurdu. Bu nedenle toplumda bir eylemin doğru ya da yanlış olduğuna karar verebilen ve kendini denetleyen, davranışlarının sorumluluğunu alabilen bireylere ihtiyaç vardır. Bu değerden yoksun olan bireyler için amaçlarına ulaşmalarında sürekli dışsal uyaranlar gereklidir.

Mert, İstanbul'a kişisel gelişim semineri için gitmiştir. Daha önce katıldığı seminerlerinde verimlilikle ilgili çok önemli şeyler öğrenmiş, yaptığ 1 iş için yeni ufuklar açmıştır bu yüzden bu seminere heyecanla yetişmeye çalışmıştır. "Daha önce katıldığım kişisel gelişim seminerlerinde de verimlilikle ilgili çok önemli şeyler öğrenmiş, yaptığım iş için beynimde yeni ufuklar açtım. İşte bu yüzdendi benim bu programı önemseyişim ve heyecanla bir an önce yetişmeye çalışmam” (BAA, 2014).

Evli ve çocuklu olduğu halde bir sevda rüzgarına kapılan Mert, Allah’tan yardım istemek için dualar ederken iç mahkemesinde kendini yargılamıştır. Yüreğindeki sevdaya yenik düşmemeye karar vermiştir. Yaşadığı iç çatışmalarla mücadele ederken İstanbul'dan, Melek'ten uzaklaşma kararı almıştır. "Daha önceleri de kendimi bu konuda sorgulamış ancak her defasında yüreğime yenik düşmüştüm. Kararlyydım ve bu sefer yenilmeyecektim yüreğimin o pervasız feryatlarma...” (BAA, 2014).

Serap hayat hikâyesini Melek'e anlatmıştır. Serap sürekli bir tartışma ortamında büyümüştür. Ancak bir gün babasının evlenmesine izin vermediği ablası çocuğuyla baba evine dönmüştür. O gece yaşanan duygusal anlardan sonra ailenin fertleri sonraki zamanlarda davranışlarını kontrol etmiş birbirlerine karşı daha iyi yaklaşmışlardır. "O güne kadar hep öfke ve nefret üzerine inşa edilen evimizi o geceden sonra buruk bir mutluluk sarıyordu. Annem artık keçileri sağmaya giderken söylenmiyor, ağabeyim ile ben dağların yolunu tutabilmek için çok erkenden kalkıyorduk” (BAA, 2014).

İkinci kez firara kalkışıp hücreye kapatılan Mahmut davranışlarını kontrol edebilseydi bunları başına gelmeyeceğini düşünmüştür. "Ne vardı ki akıllı olsaydım da iki kere firara kalkışmasaydım. Hadi birincisinde affedilmiştik, ikincisinde ise o dev surları aşıp kaçamayacağımızı bile bile ne diye oradaki insanlara ön ayak olmuş ve yakalanınca da hücreye tıkılmıştım” (D, 2012).

Cezaevi teftişinde Mahmut, içinde bulunduğu kötü şartları gösterebilmek ve yiğitçe ölmeyi istemek için elinden gelen her şeyi yapmayı düşünmüştür. "Nazır bey hazretleri içeriye girer girmez var gücümle kapıya abanacak, zayıfta olsa yumruklarmla kapıy yumruklayacak ve bir şekilde ona kendimi dinletecektim. Bu benim hayatla memat arasındaki son şansımdı ve bu defa hata yapmayı düşünmüyordum” $(D, 2012)$.

Trende geçen bir yolcukta kabin görevlilerinin bu kadar sert olmasının nedeninin çok yoğun çalıştıklarını, evden getirdikleri yemekleri dönüş gününe yetsin diye idareli olarak yemek zorunda

\footnotetext{
\begin{tabular}{r|l} 
Adres & $\begin{array}{l}\text { Address } \\
\text { İstanbul Medeniyet Üniversitesi, Eğitim Bilimleri Fakültesi, Türkçe }\end{array}$ \\
İstanbul Medeniyet University, Faculty of Education Sciences,
\end{tabular} ve Sosyal Bilimler Eğitimi Bölümü, Türkçe Eğitimi ABD Cevizli Turkish and Social Scinces Education, Turkish Language Teaching Kampüsü, Kartal-İstanbul/TÜRKIYE Education, Cevizli Campus, Kartal-İstanbul /TURKEY e-posta: editor@rumelide.com $\mid$ e-mail: editor@rumelide.com
} 
olduklarından bahsedilmiştir. "Üstelik yaklaşık dört günlük bu yolculuk strasında sefer taslarna evde ne konulmuşsa onu idareli bir şekilde yemek zorunda kahyorlard..” (DE, 2015).

Üzerine oyunlar oynandığını düşünen Asaf, görev yerinde attığı adımlara dikkat etmesi gerektiğini düşünmüştür. "Çok dikkatli olmahyım. Öyle ulu orta her yerde, herkesin yanında olur olmaz şeyler konuşmamalıyım. "Bir kere adımız çıkmış dokuza, inmez sekize...” (G, 2015).

Köy halkına ve eşlerine acımasız olan köyün ağası bir gün ağır bir hastalığa yakalanarak yatağa düşmüştür. Eşlerinin bakımı ile iyileşen ağanın aklı başına gelmiş çevresindekilere davranışını kontrol etmeye başlamıştır. "Artık hanımlarına çok kibar, marabalara karşı merhametli davranıyordu. Her öğün olmasa da günde bir iki öğün camiye gidiyor, cemaate karışıyordu (SC, 2014).

\subsubsection{Sabir}

TDK sözlük (2020)'te sabır kavramı; “Sıkıntı, maddi geçimsizlik, hakkının elinden alınması gibi kişiyi zor durumda bırakan üzücü olaylar karşısında kötü davranışlara yönelmeden başındaki sıkıntıların geçmesini bekleme olgunluğunu gösterme” olarak geçmektedir. Yaşadığı toplumda meydana gelmiş bir kriz karşısında sakin kalıp, metanet gösteren birey krizin olumsuz etkilerinin yayılmasını önler. Diğer yandan sabır göstermeyip kötü davranışlara yönelen bir kişi o krizin olumsuz etkilerini hem başka bireylere yaymış olur hem de krizi daha ileri bir boyuta taşır. Toplumda tahammül etmeyi bilen, ne zaman, nerede, ne eylemde bulunacağı belli bireylere ihtiyaç vardır. Bu insanların bulunduğu bir toplumda olası problemler ön görülebilir ve yan etkiler azaltılabilir.

Trabzon'da buluşan Mert ve Melek piknik planlarını gerçekleştirmek için yola çıkmışlardır. Ancak Mert hiçbir şey konuşmadan son süratte aracı kullanmış, Melek ise sabırsızlanmış ve sorular sormaya başlamıştır. Mert ise gidecekleri yere kadar sabırlı olmasını söylemiştir. "Sanırım pikniği Erzincan'da yapacağız..." diyor ve susuyordu. Artık onu daha fazla meraklandırmamak için suskunluğumu bozuyor ve ona sabırlı olmasın söylüyordum" (BAA, 2014).

Hapishanede kalan Mahmut arkadaşlarının deyimiyle namı diğer Çevik, hücrenin zor şartları içerisinde ayakta kalmak için kendini biraz daha dayanması, sabretmesi konusunda cesaretlendirmiş ancak bir yandan da dayanamayacă̆ını düşünmüştür. "Bazen de içimden bir ses "diren ulan Çevik, bu kışı hasarsız atlatırsan kurtulacaksın" diyordu. İnanmıyordum içimdeki o yalan söyleyen çocuğa ama yine de "ya doğru söylüyorsa!" demekten de kendimi alamiyordum" (D, 2012).

Bir köy okuluna öğretmen olarak atanan Asaf, köydeki ailelerden birisinin evine misafir olmuştur. Yemekler yenildikten sonra ailenin büyükleri tarafından Asafa zor sorular yöneltilmesi üzerine tedirgin olsa da sabrederek soruların bitmesini beklemiştir. "İçimde derin bir belirsizlik ve korku vardı aslında ama bu korkunun bu insanlara güvenmek ile yenileceğinin de farkında olarak büyük bir sabırla sorularm bitişini bekliyordum" $(G, 2015)$.

İlk görev yeri Adıyaman-Doğanlı köyü olan Asaf görev süresini tamamlayınca tayin isteyip ayrılmıştır. On beş yl sonra ilk görev yerini ziyaret eden Asaf arkadaşı Habip ziyaret etmiş bu ziyaretinde Habip’in kalp rahatsızlığı nedeniyle uzun süre hastanede yattığını, yurt dışında gelen bir cihaz sayesinde bir süre de evinde tedavi gördüğünü öğrenmiştir. Habip içinde iyileşmeye dair olan umudundan ve sabrından Asafa bahsetmiştir. "Lakin içimde bir umut günden güne büyüyor, göveriyor, yeşeriyordu. Sürekli güçlendiğimi hissediyor ve derin bir tevekkül içerisinde sabrediyordum” (G, 2015).

\footnotetext{
Adres $\mid$ Address

İstanbul Medeniyet Üniversitesi, Eğitim Bilimleri Fakültesi, Türkçe İstanbul Medeniyet University, Faculty of Education Sciences, ve Sosyal Bilimler Eğitimi Bölümü, Türkce Eğitimi ABD Cevizli Turkish and Social Scinces Education, Turkish Language Teaching Kampüsü, Kartal-İstanbul/TÜRKIYE Education, Cevizli Campus, Kartal-İstanbul /TURKEY e-posta: editor@rumelide.com $\mid$ e-mail: editor@rumelide.com
} 
Ramazan ayında personel iftara beş dakika kala aşağı yemekhaneye inmiştir. Odalardaki hastaların bebek gibi sızlanması üzerine koridordan onlara tepki olan bir ses yükselmiştir. "Biraz sabırlı olun, siz Müslüman değil misiniz? İnsanlar iftar etmeye gittiler!” İşte o sesin ardından bütün homurdanmaları kesilir ve sabırla iftara giden personelin gelişi beklenirdi” (KÇZ, 2017).

Kardelen'e mektup yazan kahraman sevdanın kendisi ve yüreğindeki için tanımını yapmıştır. "Sevdanın yüreğimdeki dervişteki tanımı gibi bendeki diğer adı da sabırdı. Susup, uzun karakış gecelerinde sabahları beklemek, umutsuz sabahlarda ise güneşin soğuk yüzüne sabredip baharlara uzanmakt” (KM, 2015).

191490 ooo Sarıkamış’ta kardeşi ile aynı anda askere alınan Kara Halil, acılarını görmemek için kardeşi ile yollarını ayırmıştır. Bu duruma sonradan pişman olan Halil, kardeşi İbrahim’i bulma umuduyla diğer birliklere malzeme taşımayı kabul etmiştir. "Oncacık yük ne yapardı ona. O kal çuvallara babasının doldurduğu zahirelere harmandan ambara kadar hiç yorulmadan taşıyordu. Dayanmahydr. İbrahim’i bulabilecekti belki” (S, 2011).

Mahallenin bakkalı Hüsnü, sadık çırağı Bilal'e bir dükkân bir de daire bırakmıştır. "Babamın çayını yudumlarken, sanki kendi büyük marifetini anlatırmış gibi ballandırarak anlattıklarından anladığım kadarıyla Hüsnü Amca yıllardır sabırla kahrım çeken, kendisine tahammül eden vefakâr çrrak Bilal'e hiç hafife alınamayacak bir bağışta bulunmuştu. Çulsuz çırak bir anda bir dükkân bir de daire sahibi olup çıkıvermişti” (YLA, 2017).

\subsubsection{Sayg1}

TDK (2020) sözlükte "değeri, üstünlüğü, yaşlılığı, yararlılığı, kutsallığı dolayısıyla bir kimseye, bir şeye karşı dikkatli, özenli, ölçülü davranmaya sebep olan sevgi duygusu, hürmet, ihtiram bir diğer anlamı Başkalarını rahatsız etmekten çekinme duygusu" olarak geçmektedir. Toplumda farklı ailelerde farklı inanışlar, görüşlerle yetiştirilen ve doğuştan getirdikleri biricik özellikleri olan bireylerin bu kadar farklılıkla bir arada yaşayabilmesinin temel koşullarından birisi saygıdır. Kendisi kadar başkalarını da düşünen, kişiliklere değer veren bireyler yetiştirmek çocuk yaşta saygı bilincinin kazandırılmasıyla sağlanabilir.

Dostu Mert ile birlikte omuz omuza bir gelecek planı yapan Mustafa Mert'in İstanbul'a döneceğini öğrenmiştir. Arkadaşının gitmesini her ne kadar istemese de onun çektiği sıkıntıları anlayan Mustafa dostunun bu kararını saygıyla karşılamıştır. "Sanki "gitme dur şurada üç günlük dünyada ömrümüzün geriye kalan günlerini sırt sırta vererek geçirelim” der gibiydi ama kopardığı lokmayı bile ağzına götüremeden kaşığın tabağının yanına koydu ve "Sen nasıl istersen... Canın sağ olsun toprağım!” dedi ve yemeğini bitirmeden sofradan kalktı” (BAA, 2014).

Melek'ten haber alamayan Mert onu görmek umuduyla hep uğradıkları mekana gitmiştir. Mekanda ortak dostları olan Selda ile karşılaşan Mert Melek'le ilgili haber alırken yanlarına Aşık Yener gelmiştir. Aşık Yener ile bir anıları aklında canlanan Mert ondan gördüğü saygıdan bahsetmiştir. "Onunla en sohbetimizde bana; "yol ver dağlar" şürin anısın anlatmış ve o zamandan sanki benim bugünkü yaşadıklarmı hafizama resmetmişti. Bana hep sevgili şair diye hitap ederdi. Bense ona "estağfurullah şair sizsiniz hocam" dediğimde, reddederek "hayır ben ozanım, sen şairsin" derdi" (BAA, 2014).

Adres

İstanbul Medeniyet Üniversitesi, Eğitim Bilimleri Fakültesi, Türkce ve Sosyal Bilimler Eğitimi Bölümü, Türkçe Eğitimi ABD Cevizli Kampüsü, Kartal-İstanbul/TÜRKIYE e-posta: editor@rumelide.com 
İlişkilerinde son sözü Melek'e bırakan Mert Melek’i bir daha aramak istemesine rağmen son görüşmesinde rahatsızlık verdiği hissine kapılınca ve Melek’in daha az görüsselim demesi üzerine aramamış, gönlündeki Melek'le baş başa kalmıştır. “Onun araması lazım, son sözü ona bırakmıştım. Buna rağmen dayanamayıp aradığımda da rahatsızlı duyduğunu hissettiğim için bir daha aramamaya kesinlikle kararliydım" (BAA, 2014).

Müslüman olmayan baba Agop’un ezan okunduğunda çalışmayı bırakma alışkanlığı dükkândaki diğer çalışanlar tarafından sürdürülmüştür. "Dükkâna döndüğümüz zaman Sala okunmaya başlamıştı. Her ezan okunduğu zaman çalışma durdurulur, ezan bittikten sonra tekrar başlanırdı. Baba Agop’tan kalma bir gelenekti bu. Agop Müslüman değildi ama ezanı dinlemekten büyük zevk aldığın söylerdi. " (D, 2012).

Okumak için Kars’a gidecek olan Hamdi, babası ile Mercan Garı'na doğru ilerlerken insanların karda yürüyerek açtığı ince çizgiden yürümüştür. Karşıdan gelen insanlara yol verebilmek için kara saplanmıştır. "Arada bir karşıdan gelenlere yol verebilmek için kenara çekildiğimde patika yolun kenarın dolduran kara saplanıyordum. Her saplanışımda ayakkabılarımın arasından çoraplarıma bir ıslakhğın sızıp tenime dokunuşu ile ürperiyordum.” (DE, 2015).

Hamdi okul için çocuk yaşta Erzincan'dan trenle Kars'a gitmiştir. Yolculukta aynı bölümde seyahat ettiği aile atıştırmak için meyve çıkarmış, Hamdi sadece adını duyduğu muzu merak ettiği için incelemek istemiştir ama insanların elindeki yiyeceğe bakmanın doğru olmayacağını düşünmüştür. Ailenin babası olan Ahmet Bey yedikleri meyvelerden Hamdi’ye de ikram etmiştir. "O zamana kadar sadece adın duyduğum muzu ilk kez yakından görmüştüm. Aslında alıp yakından incelemeyi çok istiyordum ama insanlarm ellerindeki yiyeceğe gözümü dikip bakmanın çok da hoş olmadiğı düşündüğümden o tarafa doğru mümkün olduğunca bakmamaya çalışıyordum.”(DE, 2015, s.34-35). "Cam kenarmda oturan adam yerinden kalkıyor, kadını elinden bir tane muz ve iki tane mandalina alarak bana uzatıyordu. "Yok, teşekkür ederim, yemeyeceğim..." gibi ifadelerle ikram edilen meyveleri geri çevirmek istememe rağmen, adam beni hiç dinlemeden meyveleri elime tutuşturarak yerine oturuyordu." (DE, 2015)

Adıyaman’a öğretmen olarak atanan Asaf öğretmen, bir ekiple birlikte Nemrut'u görmeye gitmiştir. Günbatımını izlemek için oluşturulan gruplardan birisine katılmak için selam vererek onlara katılmıştır. "Bir an kenardaki bir yabancı çiftin yanında bir kişilik boşluk buluyor ve hafifçe gülümseyip kafamı öne doğru eğerek bir selam veriyor ve yanlarına oturuyordum” (G, 2015).

Ana karakter Erzincan depreminin enkazından bir gün sonra çıkarılmış ve kaldırıldığı hastanede geçirdiği süreç içinde orada bulunan hasta ve refakatçiler arasındaki diyaloglardan söz edilmiştir. "Yaşça benden büyük olan adam arada bir yanindaki refakatçisini azarlyyor ve homurdanarak ağır adımlarla yürümeye devam ediyordu. Birazdan yanıma doğru yaklaşıyor duraksıyordu. Ben de duraksıyordum ve adama doğru dönerek; "Geçmiş olsun, kaza m??” diye soruyordum” (KÇZ, 2017).

Kahraman Adıyaman’a öğretmen olarak atanmıştır. Görevi için memleketinden Adıyaman'a yaptığı yolculuk sırasında yan koltuğunda oturan adam kendisine birkaç soru sormuştur. "Yaşça benden çok büyüktü ama öğretmen olduğumu, hele bir de şïr yazdiğımı öğrendiği andan itibaren bana gösterdiği kibarlık beni rahatsız etmeye ve utandırmaya başlamışt”" (KM, 2015). 
Halil ve arkadaşı Osman Rus askerlerinin eline yaralı olarak teslim düşmüştür. Askerler tarafından Kazak'taki eski ve bakımsız bir hastaneye yatırıldıktan sonra tedavilerine başlanmıştır. Hastanedeki şefkat bacısı Leyla, her sabah güler yüzü hasta odasına giriyor ve hastaları tedavi ediyordu. O gün hastaneye çok fazla yaralı getirilmiştir. Halil bu yaralıların nerden geldiğini Leyla'ya sormuş Ermenilerin Azerbaycan Türklerine saldırdığını çok fazla yaralı olduğunu öğrenen koğuştaki herkes durmadan gözyaşı dökmüştür. "Bir ara kafasın kaldırıp baktığında oradaki yarahların hepsinin gözyaşlarının durmadan aktığı dikkatini çekmiş ve "buradaki hem bedenleri hem de yürekleri yarah insanları üzmeye hakkım yok" diyerek hızla oradan uzaklaşmıştı" (S, 2011).

Doktor Umut, Gamze'nin soğuk tavırlarından kendisinden hoşlanmadığı anlamını çıkartmıştır. Buna saygı göstererek onu rahatsız edecek bir tavır sergilememe kararı almıştır. "Evet, benim ondan hoşlanmam onun da benden hoşlanacağı anlamına gelmez. Ben onu seviyorum, o benim için önemli ve değerli bir insan öyle ise onu sıkıntıya sokacak, hoşuna gitmeyecek herhangi bir davranışım olmamal.." (SC, 2014).

\subsubsection{Sevgi}

"Sevgi ilgi demektir, hoş görü demektir. Sevgi tahammül göstermek demektir. Sevgi, doğaya, çevreye, tüm canlılara karşı duyarlı ve sorumlu olmaktır. Sevgi korur, geliştirir, sevgisizlik ise yıpratır, yok eder (Özmen, 1999).” Bireyler hayvana, vatanına, insana, eşyaya sevgi besleyebilir ve bu sevgi sebebiyle bă̆ kurarlar. Bağ kurdukları şey her neyse kaybetmemek için kendilerini denetler ve olumlu yönde şekillendirirler.

Trabzon'a arkadaşının dügünü için giden Melek, Mert'ten bir gece ayrı kalabilmiştir. Biran önce İstanbul'a, Mert'in yanına dönmek istemiştir. "Her diyarda unutulan yeni bir sevdaydı ayrllk. Bir şeyler eteklerimden sımsık sarılı gitme diyor, diğer taraftan ise henüz daha adını bile koyamadığım bir sevda, ellerimi tutmuşçasına beni kendisine doğru çekiyordu” (BAA, 2014).

Melek'in yetiştirme yurdundaki arkadaşlarından birisi olan Melike kendisini ziyarete gelecek olan sevdiği kişiye sürpriz yapmak, onu otobüsten indiğinde karşılamak için erkenden yurttan ayrılmayı planlamıştır. "Melike o gün akşama doğru bir mektup almış ve mektupta, görüştüğü ve sevmeye çalıştı̆̆ çocuğun o gece yarısından sonra şehre geleceğini öğrenmişti. Hatta otobüsünün İstanbul'dan hareket saati bile yazılmıştı. Melike, yıllar sonra kendisine bu kadar değer veren bir erkeğe sürpriz yapıp otobüsten iner inmez onu karşılamayı düşünmüş olmalıydı" (BAA, 2014).

Asker arkadaşını görmeye giden Mahmut, Ökkeş’in ailesinden uzun zamandır Ökkeş’in eve uğramadı haberini alır. O köyde bir süre kalıp köydekilere okuma yazma öğreten Mahmut bir gün Ökkeş’in köye döndüğünü ve babasına sarılışını görünce aralarında nasıl bir sevgi olduğunu anlamıştır. "Ökkeş’in konağın kapısından içeri girişi ve babasına sarılışı oradaki herkes gibi beni de duygulandırmıştı. Bir baba ile oğlunun bu kadar birbirlerine tutkun olabileceklerini ilk kez görmüş̧tüm” (D, 2012).

Kalabalığın içinden Ahmet Bey sayesinde iyi bir kompartımanda kendine yer bulan yaşlı kadın Ahmet Bey'in arkasından ona teşekkür amaçlı dua etmiştir. Bir süre arkasından baktıktan sonra yanındaki küçük kız çocuğunu sevmiştir. "Yaşl kadın bir süre gözlerini dikip koridor tarafina uzun uzun baktı. Sonra geriye dönüp küçük kızın kafasına, boynuna boğazına iyice sarıp düğümlediği eşarbr gevşetti. Eli ile çocuğun başımı sıvazlayıp çocuğu birkaç kere öptü.” (DE, 2015).

\footnotetext{
Adres $\mid$ Address

İstanbul Medeniyet Üniversitesi, Eğitim Bilimleri Fakültesi, Türkçe İstanbul Medeniyet University, Faculty of Education Sciences, ve Sosyal Bilimler Eğitimi Bölümü, Türkce Eğitimi ABD Cevizli Turkish and Social Scinces Education, Turkish Language Teaching Kampüsü, Kartal-İstanbul/TÜRKIYE Education, Cevizli Campus, Kartal-İstanbul /TURKEY e-posta: editor@rumelide.com 1 e-mail: editor@rumelide.com
} 
Yıllar önce bir otobüs seyahati sırasında yolculardan birisi ile çantası karışan, eşyaları ve her şeyini yazdı̆̆ı Gökmavi isimli defterini kaybeden Asaf beklemediği bir anda görev yeri Adıyaman'dayken karakoldan gelen bir haber üzerine defterine kavuşmuştur. "Hemen yerimden kalkıyor ve çantanın fermuarın açıyordum. "Gökmavi..!" diyor ve yıllar sonra elime aldığım o sırlartmla dolu defterimi yeni doğmuş bir çocuk gibi seviyor, okşuyor ve yapraklarmı bir bir çeviriyordum” (G, 2015).

Kanayan Çiçekler Zamanı'nda yazar içinde bulunduğu çevreye sevgisini uzak ülkelere beslediği hayaller gibi nitelemiştir. "Hava alabildiğine güzeldi. Yol kenarlarmdaki yorgun çınarlarm yaprakları bile güne gülümseyerek bakıyordu. Martılarn Haliç’in kirli sularna inat Eminönü’nden kalkan vapurlara takılı boğazın keyfini çıkarışları yanı başımda olmasına rağmen uzak ülkelere beslediğim hayaller gibiydi” (KÇZ, 2017).

Yazar dă̆ yamaçlarında rastladığı bir kardelen çiçeğine sevdalanmıştır. Ve yıllarca bu sevdayı gönlünde taşımış, beslemiştir. Yüreğindeki kardelene olan sevdasını defalarca kez dile getirmiştir. "Uçsuz bucaksız koyaklarm dağ yamaçlarm sokulduğu bir noktada beyazlar içinde bir kardelen çiçeği gördüm. Yüreğimde büyüttüm onu, sevdalarm en masumuna sarllarak. Yıllar yılı sevda türküleri mırldandım onun için bitmek ve tükenmek bilmeyen namelerle inledim ardından" (KM, 2015).

Yazar ylllar önce köylerden birisinde gelinlik çağına gelmiş güzelliğiyle bilinen Nesrin’in sevda öyküsünden bahsetmiştir. Anne ve babası Nesrin’in evlilik çağına geldiği için hayırlı bir kısmet için dualar ettiği sırada Nesrin köyün imamına sevdalanmıştır. Köyde Nesrin’i çok isteyen genç olduğu için imama bu sevdadan vazgeçmesini söylemişlerdir. "Onlar "hayırl bir kısmet" için dua ede dursun, Nesrin köye yeni gelen genç imama çoktan gönlünü kaptırmışt bile. Firtınalı bir kış gününde, köyün evlenme çağına gelmiş kuzlar gibi o da kullandığı eşarbımı minareden atması için genç imamın kapısına bırakmaya gittiğinde genç imamla göz göze gelmişlerdi...” (KM, 2015).

Cephede yan yana olan Halil ve kardeşi İbrahim'in arkadaşları bir şehit olmuştur. Halil bir gün sıranın kendilerine geleceğini şehit olduklarını görmemek için ayrılmaları gerektiğini söylemiştir kardeşine. "İkisinden birisine bir hal olursa diğeri daha kendisini toparlayamazdl. Birbirlerine öylesine tutkunlardı ki. Gerçek kardeş öyle olurdu, gerçek sevgi öyle olurdu. Leyla'sindan ayrlmak, annesinden ayrılmak bile o kadar zor olmamışt İbrahim için" (S, 2011). "Arkasından bir süre baktı kardeşinin, Kara Halil. Yetim çocuk gibi boynunu büküp, kafasın bile kaldırmadan ilerliyordu tepelere doğru. Bir müddet baktı içerisinden binlerce, milyonlarca pişmanlık duyarak. Ama başka seçeneği yoktu ki. Onu o kadar çok seviyordu ki her akşam yanında yatırıyordu" (S, 2011).

Yetişme yurdunda büyüyen Zeynep okula geç kalma pahasına da olsa çok sevdiği müdür babasının gülen yüzünü görmeden okuluna gitmemiştir. "Servis müdür babadan önce geliyordu. Servise bindiği zaman Müdür Babayı göremiyor, binmediği zaman ise derse geç kalıyordu. Ama olsun, kışın o soğuk havalarda bile o kadar yolu yürümek, derse geç kalmak bile bir gülücük kadar önemli değildi” (SC, 2014).

Bir akşam evlerinin önünde bir tartışma çıkan Ali'nin babası tartışmaya müdahaleye gitmiş, oradakiler tarafından vurulmuştur. Ali babası için taziyeye gelen eş dosttan babası hakkından hep iyi adamdı sözlerini duymuştur. "Babamın mahallede bu kadar sevildiğini bu zamana kadar bilmemiştim. Onu hep kimseye fazla işi olmayan, kimseye karışmayan bir insan olarak bilmiştim. Taziye için eve gelip

Adres

İstanbul Medeniyet Üniversitesi, Eğitim Bilimleri Fakültesi, Türkce ve Sosyal Bilimler Eğitimi Bölümü, Türkçe Eğitimi ABD Cevizli Kampüsü, Kartal-İstanbul/TÜRKIYY e-posta: editor@rumelide.com 
giden komşuların: "Allah rahmet eyleye, iyi adamdı Haydar Efendi!” sözleri günlerce hatta yıllarca hep kulaklarmmda yankılanip durdu" (YLA, 2017).

\subsubsection{Sorumluluk}

Sorumluluk kavramı birçok yazar ve araştırmacı tarafından, kişinin kendi davranışlarının veya kendi yetki alanına giren herhangi bir olayın farkında olması ve davranışlarının ve durumların sonuçlarını üstlenmesi olarak tanımlanmaktadır. Ayrıca, kişinin kendi davranışlarının ve yetki alanına giren olayın sorumluluğunu hem ahlaki hem de yasal boyutta üstlenmesi beklenmektedir (Glover, 1970) (Akt. Özen, 2015). Toplumsal bir varlık olan birey, içinde yaşadığı çevreye karşı sorumluluk bilincini kazanmışsa topluma, vatanına, ailesine, işine, çevresindekilere, doğaya, sonraki nesillere karşı da sorumluluk bilincini gösterebilir. Bir toplumda sorumluluk bilincini kazanmış birey sayısı ile o toplumdaki huzur doğru orantılıdır. Her bireyin kendi üzerine düşen görevleri yerine getirmesi bir başkasının sorumsuzluğu için ayrıca bir çaba sarf etmemek demektir. Yaşanılabilir bir toplumun sürekliliği kendi sorumluluklarının bilinciyle yetişmiş nesiller ile mümkündür bu hususta sorumluluk değerinin aktarımı büyük önem arz eder.

Arkadaşı Gökşen’in düğünü için yaşadığı şehir İstanbul'dan, Trabzon'a giden Melek’in bu şehirde çocuk yuvasında kaldığı vakitlerdeki anıları gözünün önünde canlanmıştır. O dönem yurtta kalan kız çocuklarının haksızlığa uğramalarına kimsenin onların sesi olmaması gibi birçok acı olayları hatırlayınca bir kez daha sorumluluklarını bilip, ayakları üzerinde durması gerektiğini düşünmüştür. "Geçmişimden arta kalan bu acı hatıralar gözlerimin önünde canlantrken bir kez daha kendi ayaklartmin üzerinde durmam gerektiği kanaatine vartyordum. Gökşen’i kendi haline burakıp İstanbul'a kendi hayatıma dönmem gerektiğine karar verip bu akşam Trabzon'dan ayrlmalıydım" ( $B A A, 2014)$.

Mahmut'un kaldığı Dergâh'ta herkesin içinde olduğu bir iş paylaşımı yapılmıştır. Her gece bir kişi uyanık kalır kendisinden beklenilen görevleri yapar ve sabah namazından sonra görevi bir başkasına devreder."Her gün bir kişi sürekli uyanık kalır, hem olası muhtemel herhangi bir tehlikeye karşı dergâhta kalan ihvanları uyartr, hem de oradakileri teheccüd namazına ve sabah namazına kaldirtrdı" (D, 2012).

Yazar yanık türkülerinin hep kar üstüne olduğundan belki de Kardelen'e olan sevdasıyla o soğuk düşlerini ısıtma kavgasına tutulduğundan ve dedesi ile kardeşlerinin yıllar önce Sarıkamış harekâtındaki yaşadıklarından bahsetmiştir. "Kara Halil henüz bir yıl önce Balkanlardaki yıllar süren vazifesini tamamlamış, yine uzun zamandır hasret kaldığı köyüne, baba ocağına yar kucağına dönmüsstü”(KM, 2015, s.48). "Güç bela yetiştirdiği üç dönümlük çavdar ve bir dönümlük buğdayı henüz hasat edemeden yine apar topar askere alnmışt. Önce kendisi, ardından henüz on dokuzuna yeni basmış kardeşi İbrahim ve onun ardından da daha on yedisindeki Ahmet” (KM, 2015).

Enver Paşa'nın emri ile birliklere malzeme taşınacaktır. Kara Halil ile birlikte gönüllü olan askerler çuvallarla Allahuekber Dağları'nın yamaçlarına doğru yürümüşler saatlerce süre bir mücadelenin ardından görevlerini başarıyla tamamlamışlardır. İkinci görevleri için yola çıkan Halil ve arkadaşları karargâh yakınında mermilerin hedefi olmuş, iki arkadaşları şehit olmuş Halil ise dizinden vurulmuştur. Bunlara rağmen sağ kalanlar emanetlerini yetiştirmek için arkadaşlarını istemeseler de geride bırakmış ve görevlerini tamamlamak için yola devam etmişlerdir. "Saatler süren bir mücadelenin ardından akşam karanlı̆̆ında ilk görevlerini başarı ile tamamlamışlardı. Emanetleri

\footnotetext{
\begin{tabular}{r|l} 
Adres & $\begin{array}{l}\text { Address } \\
\text { İstanbul Medeniyet Üniversitesi, Eğitim Bilimleri Fakültesi, Türkçe }\end{array}$ \\
İstanbul Medeniyet University, Faculty of Education Sciences,
\end{tabular} ve Sosyal Bilimler Eğitimi Bölümü, Türkçe Eğitimi ABD Cevizli $\quad$ Turkish and Social Scinces Education, Turkish Language Teaching Kampüsü, Kartal-İstanbul/TÜRKIYE $\quad$ Education, Cevizli Campus, Kartal-İstanbul /TURKEY e-posta: editor@rumelide.com 1 e-mail: editor@rumelide.com
} 
yerine teslim etmişler geceyi orada geçirdikten sonra sabaha döneceklerdi ana karargâha” (S, 2011). "Arkadaşları çok sevdikleri Kara Halili orada burakıp gitmek istemiyorlardı ama üzerlerinde yine ulaştırmaları gereken önemli bir emanet vardı ve çok kısa zamanda yerine ulaştırmaları gerekiyordu" (S, 2011).

Susuzluktan sıkıntı çeken bir köyün her zamanki gündelik telaşlarından bahsedilmiştir. "Kadınlar ağlayan çocuklarn susturma, ihtiyaçlarm giderme derdine düşmüş, erkeklere ise her zamanki gibi malzemeleri taşıma işi kalmışt..” (SC, 2014).

Evlerinin önünde çıkan tartışma nedeniyle evdekileri Ali'nin sorumluluğuna bırakan Ali'nin babası olaya bakmak için evden çıkmıştır. "Sadece bizim evin çok yakınında bir kalabahğın olduğunu gelen seslerden fark ediyordum. Babam giderken dışarıya çıkmayın diyerek bizi uyarmış, beni ise eve

Mahalle bakkalının çırağı olan Bilal, askerlik çağında bir delikanlı olmasına rağmen bakmakla yükümlü olduğu yatalak babası nedeniyle diğer arkadaşları gibi gidip bir işe yerleşememiş mahalle bakkalında çırak olarak kalmıştır. "Mahalleden birkaç arkadaşı geçen güz bir taşeronun yanında maden işi bulmuş ve gidip kış boyunca orada çalş̧mışlardı. Bilal ise yatalak babasını ve ona bakmaya gücü yetmeyen zavallı annesini brrakıp gidememişti” (YLA, 2017).

\subsubsection{Vatanseverlik}

Vatanseverlik, insanların elde ettikleri sevgilerden toplumları, kültürleri ve kültür çevrelerini birleştirecek potansiyele sahip olan sosyolojik ve sosyal sevgi olarak nitelendirilmektedir (Ergen, 2006: 150). Alman tarihçi Heinrichvon Treitschke'ye göre gerçek vatanseverlik siyasi oluşum ile iş birliğinde olmak, ataların başarılarını takdir etmek ve bu bilinci sonraki nesillere aktarmaktır (Özkırımll, 2017).

Mert, sevdiği kadın Melek ile gittikleri mekânda buluşmuştur. Mekânda çalan Anadolu türküleri ile ikisi de duygulanmıştır. Mert, çok acılar çektiği yine de vazgeçmedikleri memleketi Erzincan'dan bahsetmiştir. "Nasıl bırakıp giderdik, Anadolu insanı sevdiğini terk etmeyi pek sevmez, terk edemez. Ondan ayrlmak bizim için ölümün diğer adıydı. Bakmayın bir mecburiyettir buralara sürükleyip getirdi bizi ama gönlümüz orada, kalbimiz orada atıyor... Acılarla sürülmüş, özlemlerle sulanmıştır toprağımız. Ekerseniz eğer can bitirir sevdiklerine, ona gönül verenlere” (BAA, 2014).

Bir yanlış anlaşılma sonucu berber Ramiz suçlu görülmüş̧tür. Ancak o güne kadar vatanına karşı bir yanlışı görülmeyen Ramiz yalnızca birkaç saat sorgulanmıştır. "Allahtan ki Berber Ramiz denilince mahalledeki herkesin aklna mütedeyyin, kendi halinde, vatanın milletini seven bir insan geliyordu. Onun bu zamana kadar devlete karşı en ufak bir münasebetsizliğine rastlayan olmamıştı" (KÇZ, 2017).

Yazar, Kardelen'e mektubunda dedesinin bedelli askerlik yapanlara inat vatani görevini nasıl yerine getirdiğinden bahsetmiştir. "Kara Halil; askere gitmemek için bedel ödeyenlere inat, yaşadığ yetmiş yıllkk ömrünü gün gün, saat saat bedel ödeyerek geçirmiş, hayatının sonunda ise yakasında bir Gazi Madalyası bile olmadan onuru ve şerefi ile göçüp gitmişti bu dünyadan. Ondan geriye ise emeği, canı ve kanı ile süslediği, Sarıkamış kalmıştı. Vatan kalmıştı” (KM, 2015).

Savaşta yaralanıp evine dönen Halil'e, annesi kardeşi İbrahim’i sormuştur. Halil, İbrahim'in hala savaşta olduğunu söylemiş annesi ise vatan için gerekirse hepsinin öleceğini söylemiştir. Halil

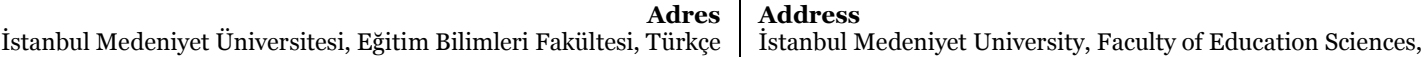
ve Sosyal Bilimler Eğitimi Bölümü, Türkce Eğitimi ABD Cevizli Turkish and Social Scinces Education, Turkish Language Teaching Kampüsü, Kartal-İstanbul/TÜRKIYE Education, Cevizli Campus, Kartal-İstanbul /TURKEY e-posta: editor@rumelide.com $\mid$ e-mail: editor@rumelide.com
} 
askerden henüz yeni dönmüşken cephede işler kötüleşince tekrar askere çağrılmıştır. "Olsun ne yapalım vatandır, gerekirse hepimiz ölürüz uğrunda” dedi Zeynep Kadın ağlamakh sesi ile” (S, 2011). "Askerden geleli henüz birkaç ay olmuştu ki savaş ihtimali yüksek olduğu için ihtiyata çağrılmış ve bir yıl süre ile ihtiyatta kalmıştı. Harp haliydi ve vatanın askere ihtiyacı vardı. Nice vatan evladı cephede çarpışırken o kaçmayı kendine yakıştıramıyordu” (S, 2011).

Üç ablasının en küçüğü, annesinin son cemresi olan şehit komiserin hayali okul dönemlerinde beri vatanının en zorlu yerlerinde hizmet etmekti ancak görev sırasında şehit olmuştur. "Akademide okuduğu ilk günlerden kafasına koymuştu. Hayatının en verimli yzllarında çocukluktan beri kendisine emeği geçenlere hizmet edecek, memleketinin en çetin yerlerinde görev edecekti” (SC, 2014,).

Çocukların oyun tekerlemelerinden birisi olarak yer verilen tekerlemede gezmeye gurbet ellerin, ölmeye ise vatanın güzel olduğu söylenen bu şiir Bağında Üzüm Kaldı isimli vatan odaklı bir şiirdir. "Sirtın, arkasındaki büyük kayaya yashyor, ucunda üç kenarl bir muska bulunan örgülü ipliği bir tespih misali elinde çeviriyor ve titreyen dudaklarnndan şu sözler dökülüyordu:

"Ezizim vatan yahşı

Geymeye keten yahşı

Gezmeye gurbet eller

Ölmeye vatan yahşı!” (YLA, 2017).

\subsubsection{Yardım severlik}

Yardımlaşma, "birinin ihtiyacı öteki tarafından temin edilen kimseler veya zümreler arasındaki karşılıklı yardımdır (Ülken, 1969). Yardımseverlik hesap kitap gözetmeden başkası için bir şey yapmaktır. Sahip olduğu güç ve imkânları başkalarının iyiliği için kullanmak; bir kimsenin sıkıntısını gidermek, o kişiye karşılaştığı güçlüklerde yardımcı olmak, yüküne omuz vermek, yükümlülüklerini paylaşmak; güç duruma düşenin güçlüğünü istekle, içten, göğsünde hiçbir sıkıntı hissetmeksizin gidermektir (Karatekin, Ekşi, Işılak, Otrar, Koç Yıldırım ve Durmuş, 2012). Elindeki imkânı ihtiyacı olanla paylaşma, başkası için fedakârlık yapma bilinciyle yetiştirilmesi gereken nesiller için yardımseverlik değeri büyük önem arz eder.

Mert, Melek ile bir sohbet sırasında ikinci hayatını yaşadığını söylemiştir. Pek anlatmak istemese de Melek'in ısrarı üzerine başından geçen talihsiz olaydan ve nasıl kurtulduğundan bahsetmiştir. "Murat'n beni çıkaramayıp yardım için uzaktaki akrabası Veysel'e gidişi ve dönüşlerinde kat ettiği yolun mesafesi, bulanan suda beni bir müddet aramaları, çıarmaları öyle beş on dakikada olması mümkün olmayacak şeylerdi” (BAA, 2014).

O dönemin bakanlarından birisi Sinop Cezaevi'ni denetlemiş hücrede ölmek üzere olan Mahmut'u görünce yanındakilere emir vermiştir. Bu emirler üzerine Mahmut o gün bir insan gibi muamele görmüştür. "Belki de bu hapishaneye geldiğim günden bu yana ilk kez kursağıma bir sıcak yemek gitmiş, hamamda yıkanmış, paklanmış ve temiz urbanlar giyinmiştim. Korumalar beni bakan takdim ettiklerinde bakanın yüzü gülüyor, mutluluğu gözlerinden anlaşllıyordu” (D, 2012).

Uzun zamandır beklediği gemiyle memleketine dönen Mahmut yolculuk sırasında geçmişe gitmiştir. Çok cana kıymış çok can yakmış olan Mahmut yaşadığı sıkıntılar aklına gelmiş arada bir yaptığı

\footnotetext{
\begin{tabular}{r|l} 
Adres & $\begin{array}{l}\text { Address } \\
\text { İstanbul Medeniyet Üniversitesi, Eğitim Bilimleri Fakültesi, Türkçe }\end{array}$ \\
İstanbul Medeniyet University, Faculty of Education Sciences,
\end{tabular} ve Sosyal Bilimler Eğitimi Bölümü, Türkçe Eğitimi ABD Cevizli Turkish and Social Scinces Education, Turkish Language Teaching Kampüsü, Kartal-İstanbul/TÜRKIYE Education, Cevizli Campus, Kartal-İstanbul /TURKEY e-posta: editor@rumelide.com $\mid$ e-mail: editor@rumelide.com
} 
iyiliklerin karşllığını gördüğünü de düşünmüştür. "Yine de arada bir yaptığım iyiliklerin karşılı̆̆ı olsa gerek birçok insandan da çok iyilik görmüştüm. Bunlarm şu ana kadar en sonuncusu Osman Reis ve arkadaşları olmuştu. Bana başımı sokacak bir yer, karnımı doyuracak bir lokma ekmek vermişlerdi” (D, 2012). "Yine bu maceraya başladığım ilk günlerde Erzurum'daki Ermeni dostlarımız bana gönüllerini açmışlar ve onların bu büyüklükleri karşısında mahcup olmuştum” (D, 2012).

Mahmut, Ermenistan'da konaklamak için geldiği bir köyde zamanında Türkiye'de yaşamış sorunlar çıkınca geri dönmek zorunda kalmış bir aile ile tanışmıştır. Tanışma sonrası Mahmut'un dedesi ve babasının zamanında bu aileye yardım ettiği orta çıkmıştır. Bu aile Mahmut'a yardımcı olmak için ne için oralara geldiğini sormuştur.

"Ne gezersin bu yaban ellerde böyle?

"Kader diyelim gitsin”. Dedim.

"Bilmemizde bir sakınca yoksa anlat, belki bir yardımımız dokunur sana” (D, 2012).

Mahmut, kurduğu çetesiyle dağlardayken bir köye eşkıyaların baskın yaptığı fark etmiş ve köylüye yardım ederek eşkıyaları alt etmişlerdir. Kurtardıkları köylüler tarafından o gece güzel bir şekilde ağırlanmışlardır. "Şayet önemli bir şey olursa biz karşı tepelerdeyiz, orada geceyi geçireceğiz bir işaret vermeniz yeterli” dedim ve karşı ki tepelere doğru yol aldık” (D, 2012).

İstasyonda bekleyen yolculara simit satan adama aşırı pahalı sattığı gerekçesiyle yaşlı bir adam tepki göstermiştir. Yaşlı adamın çaresizliği gören başka birisi kendi simidini yerken bir tane de yaşlı adam için almıştır. "Aldığı simidi; perişan halde, büzüşerek oturan ihtiyar adama uzatıyordu. Adamın olanca ısrarına rağmen ihtiyar, simidi almamakta direniyordu.” (DE, 2015).

Bir köy okuluna öğretmen olarak atanan Asafın köydeki kişiler tarafından gördüğü yardımlardan bahsedilmiştir. "Hacı Bey bu köye geldiğim ilk günden beri bana sahip çıkmış, yedirip içirmişti. Misafire hizmet etmekte hiçbir sınır tanımadıkların bana gösterdikleri ilgi ve iltifattan anlamak mümkündü” (G, 2015).

Yazar, Erzincan'da Terzi Baba olarak bilinen Muhammed Vehbi'ye ait bir anekdot anlatır. "Muhammed Vehbi, bu fakir-i seyyahin arzusunu yerine getirmeyi kabul etti. Ona; 'paltonu birak, inşallah yarma hazırlarm." dedi. Muhammed Vehbi paltoyu alıp, güzelce yıkadı kuruttu, dikti. Ertesi gün o fakire teslim etti. Bütün bu yaptıklarının karşılı̆ında ücret almadı. O fakir zat paltosunu temizlenmiş, dikilmiş görünce çok memnun oldu. Muhammed Vehbïye nazar edip, kalben dualar etti" (KM, 2015).

Arkadaşlarıyla birliğe malzeme taşıyan Mehmet kurşunların ortasında kalmış, o durumda da Halil'e yardım etmiştir. "Hemen Halil'in yanına döndü. Bir avuç su aldı yanlarından akan sudan. Halil'in yüzüne ve boynuna sürmeye başladı. Halil derin derin nefes almaya başladı ve kendisine gelmeye başluyordu" (S, 2011).

Bir çocuk yurduna atanan Murat Öğretmen’in, problemli öğrenci Yasemin'e yardımı anlatılır. "Yaşamış olduklar onun hayatın ve hayata bakış şeklini öylesine şekillendirmişti ki, çevresinde sorunlu insan görmeye tahammül edemiyordu Yasemin. Gördüğü ve tanıştığı bütün insanlara iyilik dağıtan bir iyilik meleği olmuştu adeta. Sinff arkadaşlarının sorunlarmı dinleyip onlara çözüm bulmaktan zevk almaya başlamıştı." (SC, 2014).

\footnotetext{
\begin{tabular}{r|l} 
Adres & Address \\
İstanbul Medeniyet Üniversitesi, Eğitim Bilimleri Fakültesi, Türkçe & İstanbul Medeniyet University, Faculty of Education Sciences,
\end{tabular} ve Sosyal Bilimler Eğitimi Bölümü, Türkçe Eğitimi ABD Cevizli Turkish and Social Scinces Education, Turkish Language Teaching Kampüsü, Kartal-İstanbul/TÜRKIYE Education, Cevizli Campus, Kartal-İstanbul /TURKEY e-posta: editor@rumelide.com 1 e-mail: editor@rumelide.com
} 
Ali askere alınmış o askerdeyken Ermeniler Türk köylerine baskın yapmış, köylerde kimse kalmadığı haberleri yayılmıştır. Düşmana bir kurşun bile sıkmadan savaş bitmiş Ali ve arkadaşları Iğdır’a getirilmiştir. Ali zor da olsa bir köye sığınmak istemiştir. Bu köyün ağası hep tanışmayı hayal ettiği Abbas Ağa çıkmıştır. "Çocukluğumda hep hayalini kurduğum Abbas Ağa’yı da tanımış ve onunla konuşma firsatı bulmuştum. Başımızdan geçenleri anlattığımda çok üzülmüş ve istediğim kadar kalabileceğimi de söylemişti” (YLA, 2017).

Çalışmaya ilişkin bulgular genel olarak aşağıdaki tablo ve şekillerde belirtilmiştir: Dokuz eserdeki toplam değer sayısının 437 olduğu saptanmıştır.

Hamdi Ülker'in eserlerinde tespit edilen değerlerin işlenme sıklı̆̆ı ve yüzdesi Şekil 1 ve Şekil 2 olarak gösterilmiştir. Şekillere bakıldığında eserlerde on kök değerin hepsine yer verildiğii, en çok işlenen değerin yüz otuz dokuz örnekle sevgi değeri, en az işlenen değerin sekiz örnekle adalet değeri olduğu görülmüştür.

Tablo 5. Ülker’in Eserlerinde Tespit Edilen Kök Değerlerin Dağılımı

\begin{tabular}{|c|c|c|c|c|c|c|c|c|c|c|}
\hline & 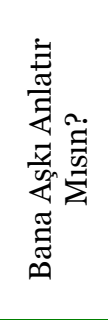 & 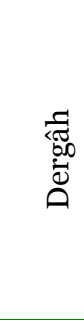 & 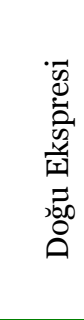 & 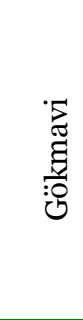 & 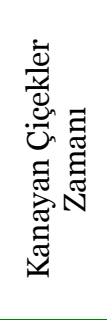 & 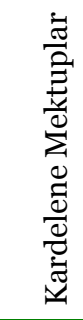 & 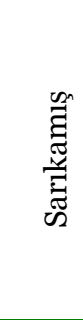 & 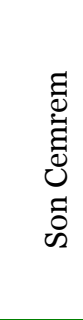 & 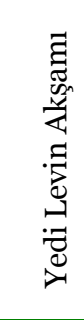 & 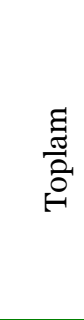 \\
\hline Adalet & 2 & 5 & - & - & - & - & - & 1 & - & 8 \\
\hline Dostluk & 18 & 10 & - & 2 & 2 & 1 & 4 & - & 1 & 38 \\
\hline Dürüstlük & 9 & - & 1 & - & - & - & - & 1 & 1 & 12 \\
\hline Öz denetim & 13 & 11 & 1 & 1 & - & - & - & 2 & - & 28 \\
\hline Sabır & 9 & 13 & - & 4 & 2 & 4 & 4 & - & 1 & 37 \\
\hline Sayg1 & 16 & 10 & 3 & 5 & 3 & 2 & 8 & 1 & - & 48 \\
\hline Sevgi & 71 & 5 & 4 & 9 & 2 & 29 & 12 & 5 & 2 & 139 \\
\hline Sorumluluk & 13 & 5 & - & - & - & 2 & 5 & 2 & 4 & 31 \\
\hline Vatanseverlik & 1 & - & - & - & 1 & 1 & 9 & 1 & 1 & 14 \\
\hline Yardım Severlik & 20 & 22 & 6 & 10 & - & 2 & 11 & 8 & 3 & 82 \\
\hline Toplam Değer Sayısı & 172 & 81 & 15 & 31 & 10 & 41 & 53 & 21 & 13 & 437 \\
\hline
\end{tabular}

\footnotetext{
Adres $\mid$ Address

İstanbul Medeniyet Üniversitesi, Eğitim Bilimleri Fakültesi, Türkçe İstanbul Medeniyet University, Faculty of Education Sciences, 


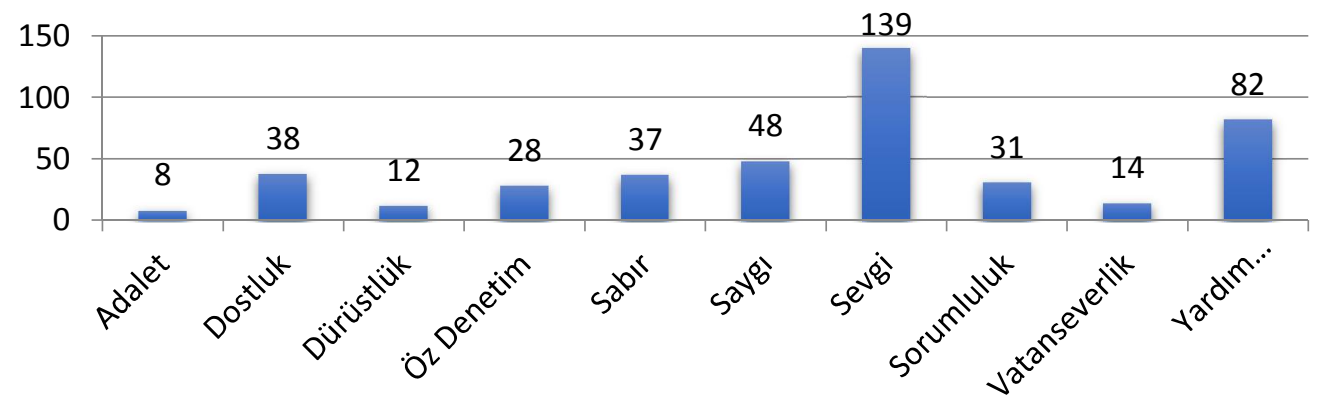

Kök Değerlerin Sıklığı

Şekil 1. Hamdi Ülker’in eserlerinde yer alan kök değerlerin sıklı̆̆ı.

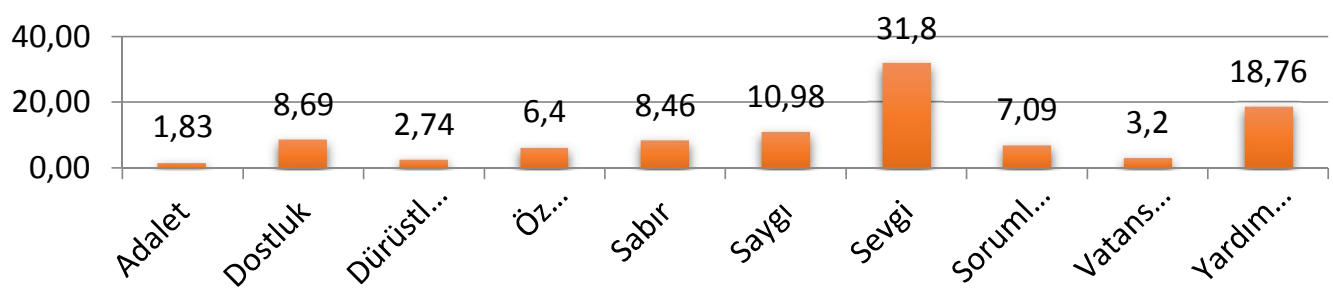

Kök Değerlerin Yüzdesi

Şekil 2. Hamdi Ülker’in eserlerinde yer alan kök değerlerin yüzdesi.

\section{Sonuç ve öneriler}

Milli Eğitim Bakanlığı 2017 yılı öğretim programı değişikliği sürecinde, değerler eğitimini gündeme getirmiş ve değerler eğitiminde esas kılınması gereken on kök değeri belirtmiştir. Hamdi Ülker'in dokuz eserini programda söz edilen on kök değer açısından incelediğimiz bu çalışmada, elde ettiğimiz sonuçlara göre Hamdi Ülker’in incelenen tüm eserleri, değerler eğitimi açısından yeterli görülmüştür. Eserlerdeki değerlerin işlenme sıklı̆̆ına bakıldığında "adalet" değerinin 8, "dostluk" değerinin 38 , "dürüstlük" değerinin 12, "öz denetim" değerinin 28, "sabır" değerinin 37, "saygı" değerinin 48, "sevgi" değerinin 139, "sorumluluk" değerinin 31, "vatanseverlik” değerinin 14, "yardımseverlik" değerinin 82 kez vurgulandığı tespit edilmiştir. Eserlerde tespit edilen toplam değer sayısı 437'dir. Eserlerdeki değerler, yüzdelik oran olarak şu şekildedir: Adalet \%1,83; dostluk \%8,69; dürüstlük \%2,74; öz denetim \%6,4; sabır \%8,46; sayg1 \%10,98; sevgi \%31,8; sorumluluk \%7,09; vatanseverlik \%3,2; yardımseverlik \%18,76.

Hamdi Ülker'in eserlerinde kök değer kategorisinde en çok sevgi değerine rastlanılmıştır. Sevgi değerinden sonra sırayla en çok işlenen değerler yardımseverlik, saygı, dostluk, sabır, sorumluluk, öz denetim, vatanseverlik, dürüstlük ve adalet'tir. Dostluk değerleri için, sadık olma, vefalı olma, yardımlaşma davranışlarının vurgulandığı görülmüştür. Dürüstlük; sözlü olma, güvenilir olma ve açı, anlaşılır olma davranışları vurgulanmıştır. Kahramanların kendi iç dünyasında aldığı kararlar üzerinden okuyucuya iletilen değerlerde alınan kararları uygulamak zor olsa bile kararlar doğru olduğu için davranış kontrolü yapıldığının ve davranış sorumluluğu üstlenildiğinin vurgulandığı görülmektedir. Sabır; tahammül etme, doğru anı beklemeyi bilme şeklinde anlatılmıştır. Yazar inanışlara gösterilmesi gereken saygıya da eserdeki olaylarla vurgulamıştır.

\footnotetext{
\begin{tabular}{r|l} 
Adres & Address \\
İstanbul Medeniyet Üniversitesi, Eğitim Bilimleri Fakültesi, Türkçe & İstanbul Medeniyet University, Faculty of Education Sciences,
\end{tabular} ve Sosyal Bilimler Eğitimi Bölümü, Türkçe Eğitimi ABD Cevizli $\quad$ Turkish and Social Scinces Education, Turkish Language Teaching Kampüsü, Kartal-İstanbul/TÜRKIYE $\quad$ Education, Cevizli Campus, Kartal-İstanbul /TURKEY

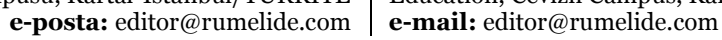


Ülker’in eserlerinde; aile birliğine önem verme, fedakârlı yapma, güven duyma, merhametli olma, vefalı olma davranışlarının vurgulandığı görülmektedir. Memleket sevgisini, Allah sevgisini, doğa ve hayvan sevgilerini de işlemiş, okuyuculara bunlar üzerinden de sevgi değerini ilettiği tespit edilmiştir. Sorumluluk değerleri; kendine, çevresine, vatanına, ailesine karşı sorumlu olma; sözünde durma, tutarlı ve güvenilir olma, davranışlarının sonuçlarını üstlenme davranışları vurgulandığı görülmektedir. Vatanseverlik değerleri incelendiğinde çalışkan olma, kurallara ve kanunlara uyma, sadık olma davranışlarının vurgulandığı görülmektedir. Yardımseverlik değeri; iş birliği yapma, merhametli olma, misafirperver olma, paylaşma davranışlarının açılımıdır.

Eserlerin hepsini ele aldığımızda yazarın, en fazla sayıda ve türde değere yer verdiği "Bana Aşkı Anlatır Mısın?” adlı eseridir. On kök değerin tamamına yer verilen tek eser olsa da eserlerin genelinde birden fazla kök değere rastlanılmıştır. En az sayıda değerin tespit edildiği eser "Yedi Levin Akşamı" adlı eserdir. Hamdi Ülker, eserlerindeki değerleri bir nasihat ya da bir kural gibi işlemek yerine çocuklara olayları sorgulatacak ve kahramanların duygularını içselleştirecek şekilde işlemiştir.

\section{Hamdi Ülker ve eserleri}

Öğretmen yazarlardandır.(1969'daCennetpınarı köyü/Çayırlı/Erzincan'da doğdu - 21 Mayıs 2019'da Erzincan'da öldü). İlkokulu köyünde okudu. Kars-Susuz Kazım Karabekir Öğretmen Lisesi ve Erzincan Eğitim Fakültesi’nden mezun oldu (1991). Anadolu Üniversitesi Açı Öğretim Fakültesi’nde lisans tamamladi.

Ülker, 1991'de Adıyaman'da öğretmenliğe başladı. On iki yll görev yaptığı bu şehir, onun yazarlık hayatının başlangıcıdır. İlk hikâyesi 1991'de Adıyaman'da kaleme aldığı "Teşi”dir. Sonrasında Tekirdağ/Çerkezköy'de iki yıl görev yaptı ve kurumlar arası geçiş yaparak Erzincan Kız Yetiştirme Yurdu'na öğretmen olarak atandı. İki yl müdürlüğünü de yaptığı bu kuruluşta sekiz yll çalıştıktan sonra yine Aile ve Sosyal Politikalar Bakanlığı'na bağlı Engelsiz Yaşam Merkezine öğretmen olarak atandı. Hikâye ve romancılığının yanında bir yerel gazetede köşe yazıları yazdı. Öğretmen bir hanımla evli ve bir oğlu olan Ülker, en verimli çağında kanser hastalı̆̆ına yenik düşerek aramızdan ayrıldı (2019).

Eserleri:

Ülker, H. (2011). 1914-9oooo Sarıkamış. İstanbul: Mola Kitap Yayın-Dağıtım.

Ülker, H. (2012). Dergah. İstanbul: Kule Kitap.

Ülker, H. (2014). Son cemrem. İstanbul: Tilki Kitap.

Ülker, H. (2014). Bana aşkı anlatır mısın? İstanbul: Tilki Kitap.

Ülker, H. (2015). Doğu ekspresi. İstanbul: Tilki Kitap.

Ülker, H. (2015). Kardelene Mektuplar. İstanbul: Tilki Kitap.

Ülker, H. (2015). Gökmavi. İstanbul: Tilki Kitap.

Ülker, H. (2017). Yedi levin akşamı. İstanbul: Kule Kitap.

Ülker, H. (2017). Kanayan çiçekler zamanı. İstanbul: Kule Kitap. 


\section{Kaynakça}

Albayrak, N. (2004). Ansiklopedik Halk Edebiyatı Sözlüğü. İstanbul: Leyla ile Mecnun Yayıncılık.

Akbaba Altun, S. (2003). Eğitim Yönetimi ve Değerler. Değerler Eğitimi Dergisi, 1(1), Ocak 2003, 718.

Bowen, G. A. (2009). Document analysis as a qualitative research method. Qualitative Research Journal, 9( 2), 27-40.

Ergen, G. (2006). Eleştirel-bilinçli sevgi eğitimi. Burdur Eğitim Fakültesi Dergisi, 8(12), 144-152.

Ekşi, H. (2003). Temel insanî değerlerin kazandırılmasında bir yaklaşım: Karakter eğitimi programları. Değerler Ĕ̆itimi Dergisi, 1(1), 79-96.

Fraenkel, J. \& Norman, W. (2000). How to Design andEvaluateResearch in Education (4th Edt.). Boston: McGraw-Hill.

Hökelekli, H. ve Gündüz, T. (2007). Üstün yetenekli çocuklarm değer yönelimleri ve eğitimleri. (Editörler: R. Kaymakcan, H. Hökelekli, Ş. Arslan ve M. Zengin), Değerler ve Değer Eğitimi, İstanbul: Değerler Eğitimi Merkezi Yayınları.

Karatekin, N., Ekşi, Işılak, H., Otrar, M., Koç Yıldırım, P. ve Durmuş, A. (2012). Perese değerler eğitimi öğretmen kitabı, yardımseverlik. Ankara: Nobel Akademik Yayıncılık.

Kelsen, H. (2013). Adalet Nedir? (Çev. Ali Acar). Türkiye Barolar Birliği Dergisi, 107, 432-454.

Özen, Y. (2015). Sorumluluk Eğitimi. Ankara: Vize Basın Yayın.

Özmen, F. (1999). Etkili Eğitimin Gerçekleştirilmesinde Duyuşsal Alanın Önemi-Sevgi Eğitimi. Furat Üniversitesi Sosyal Bilimler Dergisi, 9(1), 193-198.

Özkırımlı, U. (2017). Milliyetçilik Kuramları Eleştirel Bir Bakış. Ankara: Doğu Batı Yayınları.

Poyraz, H. (2012). Bir Değer Olarak Arkadaşlık. Cogito Dergisi, 196-206.

Tan Ç.. ve Töremen, F. (2010). Eğitim Örgütlerinde Adalet: Kavramsal Bir Çözümleme. Dicle Üniversitesi Ziya Gökalp Eğitim Fakültesi Dergisi, 14, 58-70.

Türk Dil Kurumu-TDK. (2005). Türkçe Sözlük. TDK: Ankara: Türk Dil Kurumu Yayınları:549.

Ülken, H. Z. (1969). Sosyoloji Sözlüğü. İstanbul: Milli Eğitim Basımevi.

Yel, S. ve Aladă̆, S. (2009). Sosyal Bilgilerde Değer Öğretimi. (Editör: M. Safran). Sosyal Bilgiler Öğretimi, Ankara: Milli Eğitim Yayınevi.

Yıldırım, A. ve Şimşek, H. (2018). Sosyal Bilimlerde Nitel Araştırma Yöntemleri (11. Basım). Ankara: Pegem Akademi Yayıncılık.

\footnotetext{
Adres Address

İstanbul Medeniyet Üniversitesi, Eğitim Bilimleri Fakültesi, Türkçe İstanbul Medeniyet University, Faculty of Education Sciences, ve Sosyal Bilimler Eğitimi Bölümü, Türkçe Eğitimi ABD Cevizli Turkish and Social Scinces Education, Turkish Language Teaching Kampüsü, Kartal-İstanbul/TÜRKIYE $\quad$ Education, Cevizli Campus, Kartal-İstanbul /TURKEY e-posta: editor@rumelide.com 1 e-mail: editor@rumelide.com
} 